James Madison University JMU Scholarly Commons

Masters Theses

The Graduate School

Spring 2014

\title{
An exploration of a sport club president's experience
}

Megan Lynn Flosdorf

James Madison University

Follow this and additional works at: https://commons.lib.jmu.edu/master201019

Part of the Kinesiology Commons

\section{Recommended Citation}

Flosdorf, Megan Lynn, "An exploration of a sport club president's experience" (2014). Masters Theses. 211.

https://commons.lib.jmu.edu/master201019/211

This Thesis is brought to you for free and open access by the The Graduate School at JMU Scholarly Commons. It has been accepted for inclusion in

Masters Theses by an authorized administrator of JMU Scholarly Commons. For more information, please contact dc_admin@jmu.edu. 
An Exploration of a Sport Club President's Experience

Megan L. Flosdorf

A thesis submitted to the Graduate Faculty of

\section{JAMES MADISON UNIVERSITY}

In

Partial Fulfillment of the Requirements

for the degree of

Masters of Science

Department of Kinesiology

May 2014 


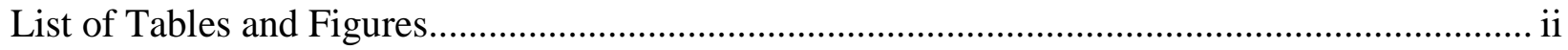

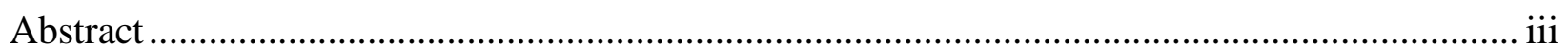

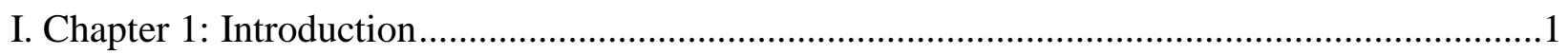

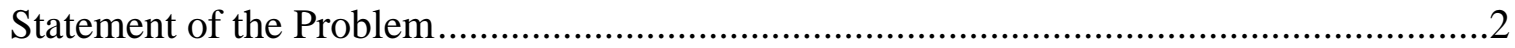

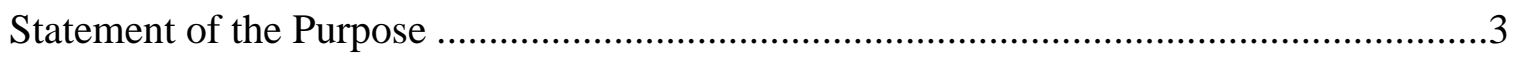

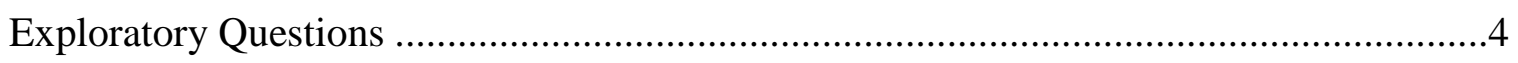

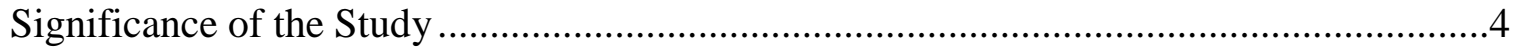

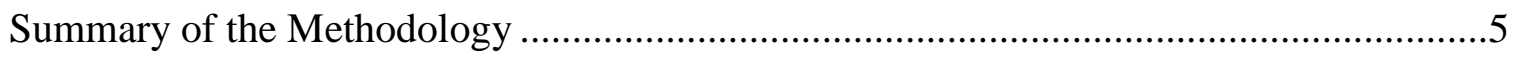

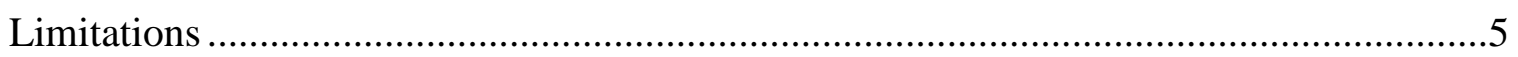

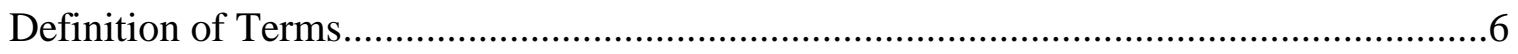

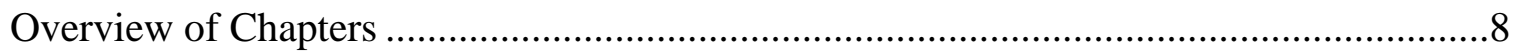

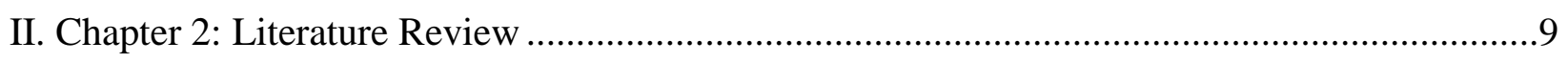

Student Development and Involvement .............................................................11

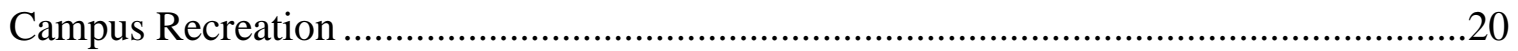

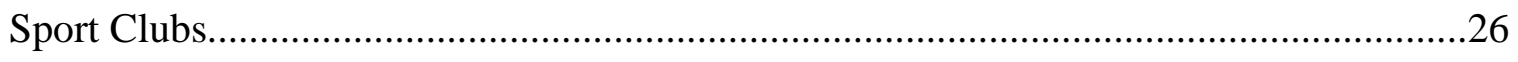

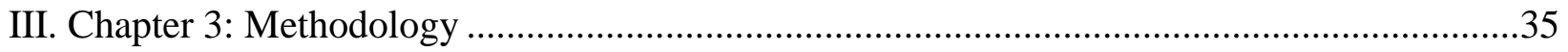

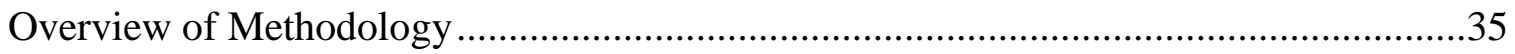

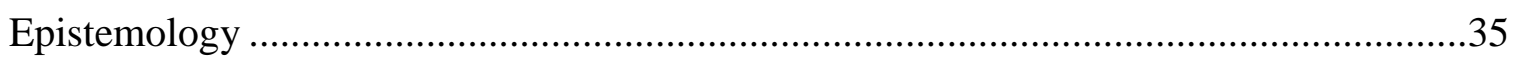

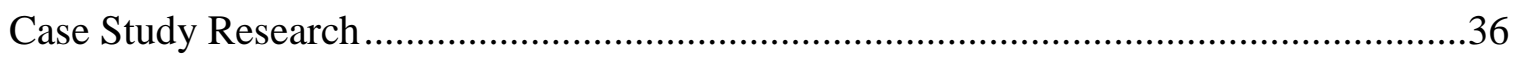

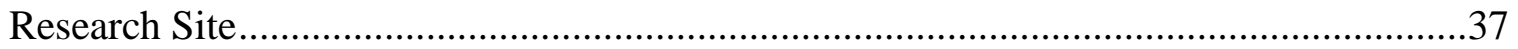

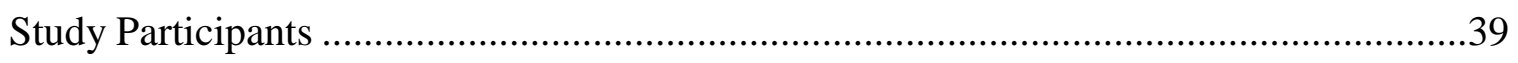

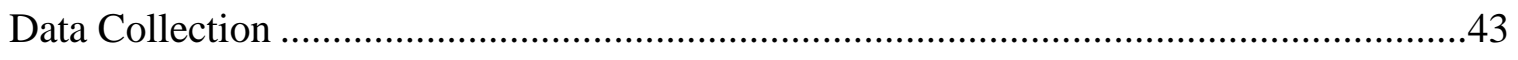

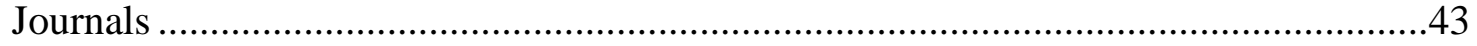

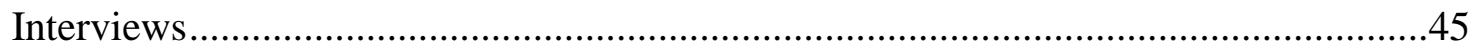

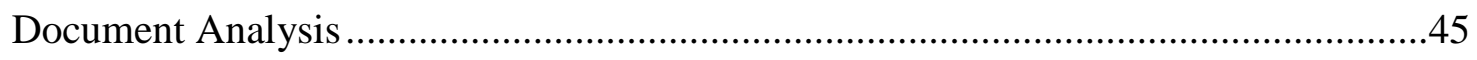

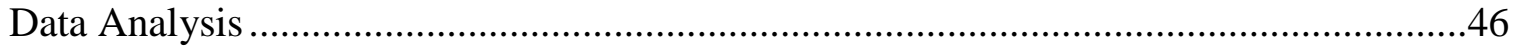

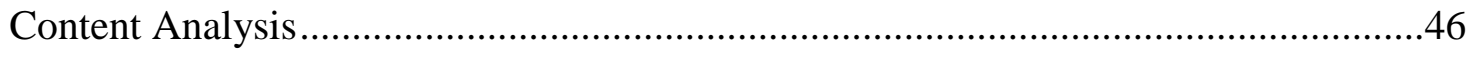

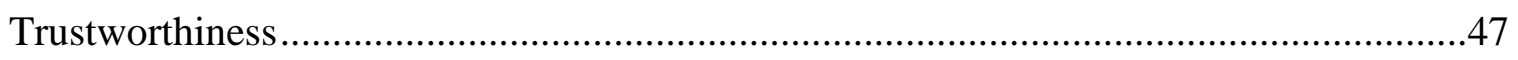

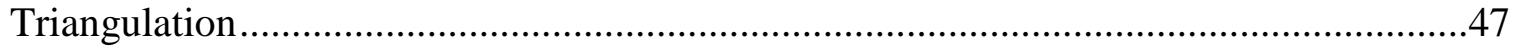

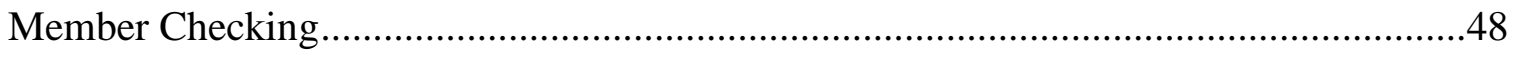




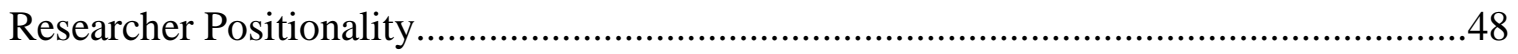

Human Participants and Ethics Precautions ……………………………………….......49

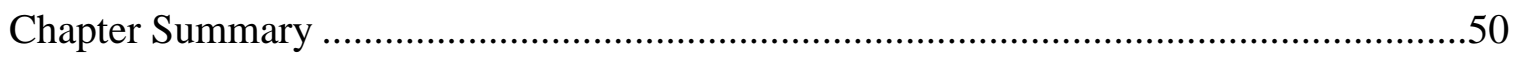

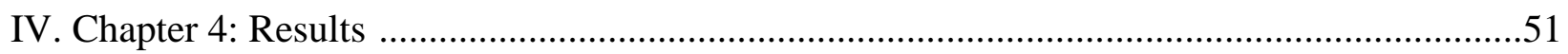

Findings by Data Collection Method...........................................................................

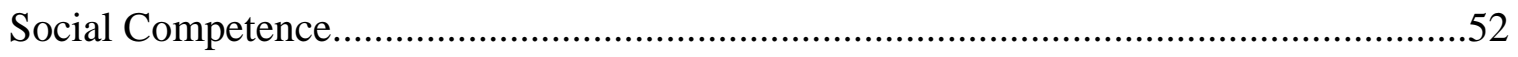

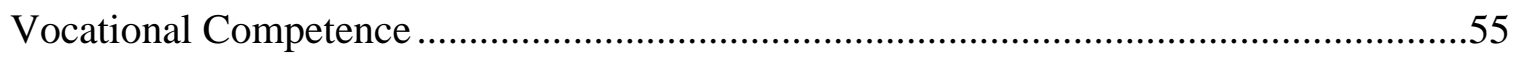

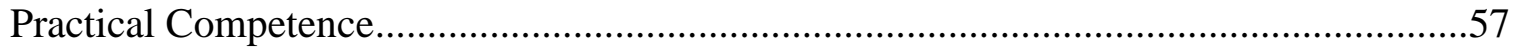

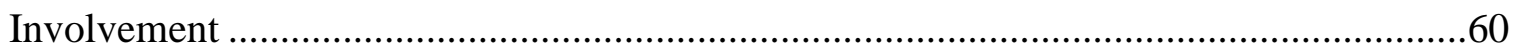

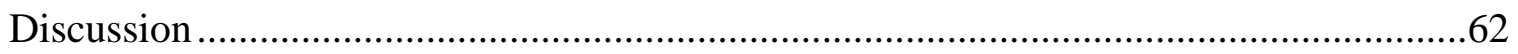

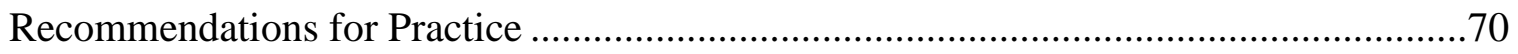

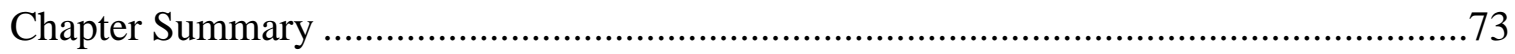

V. Chapter 5: Conclusions and Future Research ..........................................................................74

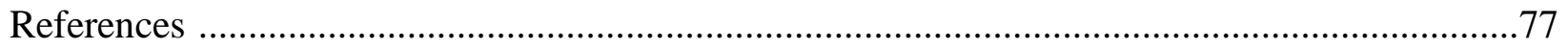

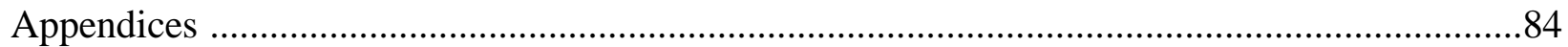

A: Letter for Research Site Approval ........................................................................8

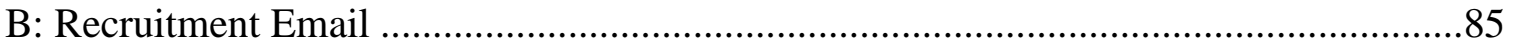

C: Recruitment Briefing Information Sheet...............................................................86

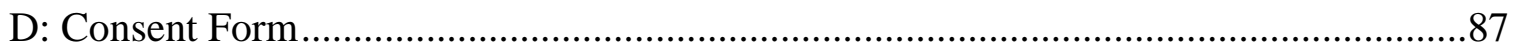

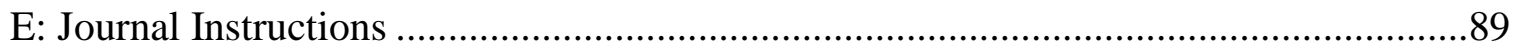

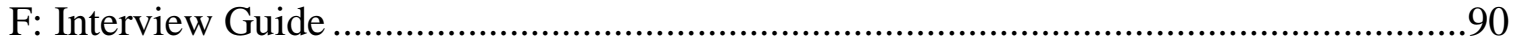




\section{List of Tables}

Table 1. Literature: Student Development and Involvement.......................................11

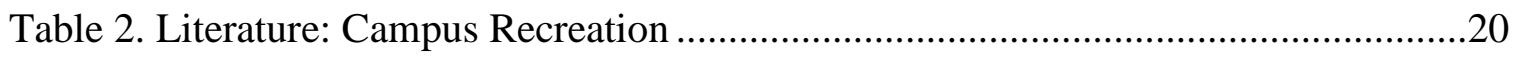

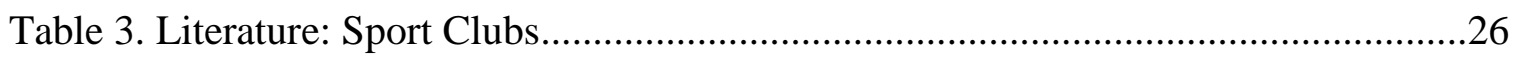

Table 4. Study Participant Demographics .................................................................42 


\section{List of Figures}

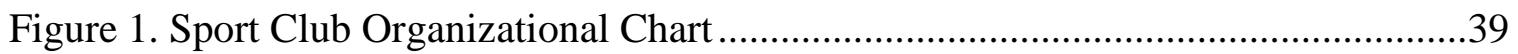




\begin{abstract}
This constructivist case study explored how sport club presidents at an institution describe their experience. Eleven sport club presidents, five females and six males, participated. They shared their experience through reflective journals and 30 minute semi-structured interviews. Document analysis was conducted for triangulation of the data. Four themes were constructed from the analysis: social competence, vocational competence, practical competence, and involvement. These findings suggest that leadership opportunities within sport club programs, through campus recreation, offer developmental experiences for students. Practical implications are given for sport club professionals and students interested in holding leadership positions.

Keywords: sport clubs, campus recreation, student development, involvement, sport club president
\end{abstract}




\section{Chapter 1: Introduction}

Is college worth the investment of time and resources? As the demand and cost of college increases, consumers, lawmakers, and administrators will continue to question the value of a student's involvement. Among the questions that need answers are: "What are students learning? What differences are you making in their lives?” (Keeling, 2006, p. 19). In response to these questions, the Council of Regional Accrediting Commissions (2003) stated that evidence of student learning is demonstrated from many sources such as the classroom and co-curricular programs. This evidence "portrays the impact on the students of the institution as a whole" (as cited in Keeling, p. 19). Additionally, Keeling emphasized that the "potential for learning exists in a variety of forms" and educators can create environments that will progress students in their development (p. 11). One avenue for learning on the college campus is involvement outside of the classroom.

According to Kuh, Kinzie, Schuh, and Whitt (2005), "what students do during college counts more for what they learn and whether they will persist in college than who they are or even where they go to college" (p. 8). Therefore, a student's involvements in both out of class and in class experiences are the core of his or her college experience. Sites for learning activities can be charted on a learning environment map to distinguish the potential places for learning on the college campus. One of the co-curricular programs that demonstrates the institution's impact and can serve as a site on the learning environment map is campus recreation. Through on-campus leadership opportunities, specifically sport club programs, campus recreation is a way for students to become involved in their college experience. 
According to investigations on the involvement of students in sport club programs, their participation affects their development (Haines \& Fortman, 2008; HallYanessa \& Forrester, 2004; Hall, Forrester \& Borsz, 2008; Hall-Yanessa \& Forrester, 2005; Weis, 2007). Furthermore, the National Intramural Recreational Sports Association (NIRSA) (2008) emphasizes student learning through involvement in sport clubs by stating, "sport clubs are...meant to be a learning experience for the members" (p. 170). More studies need to be conducted to support the emphasis that the NIRSA claims on student learning. Outcomes from participation must be evident and related to the mission of the institution in order for sport club programs to continue receiving support and viewed as a requisite on campuses. Practitioners need to document the development of students as a result of involvement in their programs, such as the present study. A question to guide the present research was: How do sport club presidents describe their experience?

\section{Statement of the Problem}

Most of the studies that exist on sport club programs focus on logistics, risk management, travel, injury, budgeting, satisfaction and conduct, and are mostly quantitative in nature (Arnold, 1975; Lifschutz, 2012; Matthews, 1979; McGregor, 1995; Palmateer, 1977; Tsigilis, Masmanidis, \& Koustelios, 2009; Tsiotsou, 1998). HallYanessa (2005) also recognized that there is little evidence that documents the development of leadership skills of students who serve in officer roles and volunteer student positions on campus. Hall, Forrester, and Borsz (2008) addressed this gap through their assessment on the learning that occurs by serving the role of a sport club officer. However, the president, who is the member given the most responsibility 
according to the Sport Club Manual, has not been the focus of research and less is known about this involvement as opposed to general members (Foubert \& Grainger, 2006).

Although Hall et al., (2008) addressed this research gap by exploring students involved in sport club leadership roles (e.g., president), there is a need for more studies to explore the president of a sport club's involvement across different institutions.

Chickering and Reisser (1993) identified the context of the institution, such as institutional size and objectives, as variables to be considered regarding a student's development. Therefore, different institutions should be assessed because of the variety of outcomes that can result.

In addition, Gellin (2003) stated, "there is a need for research focused on specific involvement areas" (p. 50). Equally important is clarifying types of involvement (e.g., student government, greek life and campus recreation) and the outcomes that result from participation because different forms of involvement may be associated with different outcomes. For example, what particular forms of involvement facilitate which aspects of a student's development? Further research needs to be conducted in order to give specific recommendations to given institutions, since there is a need to know which activities align with which outcomes, while considering the environment.

Student affairs professionals should not assume that students benefit equally from their efforts; the evidence that exists on student leadership in various organizations cannot be generalized across settings. Pascarella and Terenzini (2005) posit "not all students benefit equally from the same experience" (p. 10). There is a need to understand the development of many different students because of individual differences. The 
present study will contribute to the literature on student leadership and development through sport club involvement in the field of campus recreation.

\section{Statement of the Purpose}

This project will advance the understanding of a sport club leader's experience at a midsized institution in the Mid-Atlantic region of the United States. The purpose of this study was to explore a sport club president's experience.

\section{Exploratory Questions}

The following questions guided this exploration.

RQ1: How do club sport presidents describe their involvement in the club sport program?

RQ2: How does their involvement as a president shape their college experience? RQ3: In what ways do presidents perceive their development as result of their involvement?

\section{Significance of the Study}

This study is significant for two reasons. First, student affairs administrators, specifically sport club professionals, can use this research to illustrate how their programs and academic departments share a common goal of guiding students to develop their cognitive and affective abilities. Through this research the college community will have a better understanding of how campus recreation contributes to the broader academic mission of the institution through a rich, holistic description of a student leader's participation. Secondly, this study will demonstrate how sport club programs serve as an avenue for student involvement and leadership roles on the campus. 


\section{Summary of the Methodology}

The research was conducted using a qualitative research tradition. An intrinsic case study was performed to describe the president's experiences. This research design allowed for rich and holistic data to construct from the researcher and study participants. The case consisted of 11 sport club presidents. Data were collected utilizing three methods: journals, interviews and document analysis. The presidents submitted journals electronically each Sunday for an eight-week period and the interviews were conducted over one week. Content analysis was utilized to make meaning from the data. The constant comparative method was conducted to find commonalities between and among the interview transcripts, journals and documents. The methodology for this study is discussed in greater detail in Chapter Three.

\section{Limitations}

When interpreting the results, several limitations need recognition. First, the researcher created a limitation for the study. She was the Graduate Assistant for the sport club program. She worked with four of the participants in the past, served as a mentor for them and had contact with them outside of the research study. This may have created bias towards certain aspects of those four participant's perceptions. Also, the participants may have behaved in different ways to appear to agree with what they perceived to be the researcher's opinions.

A second limitation was the timing of data collection. Due to the researcher's timeline, data collection was required to take place half way through the president's experience. As a result, the presidents served in their roles for less than a year prior to the interview and journaling. Their experiences could have been described differently if the 
data collection was conducted later into their role or throughout their presidency. An additional timing issue was that, each sport club competes throughout different semesters. The presidents that recently completed their season may describe their experience differently than those presidents who spent the semester preparing for future competition.

A delimitation to this study, a limitation that the researcher chose, was that only presidents from the given institution served as the case. The researcher did not attempt to explore sport club programs at other universities. This may have shaped the results of this study because other programs had different policies and procedures as well as organizational structures and this could have influenced the president's experiences.

\section{Definition of Terms}

To ensure the writer and reader can effectively communicate, the following definitions are provided for clarity.

Sport club: A sport club is

"a group of students who voluntarily organize to further their common interests in a sport through participation and competition. The majority of their funds are selfgenerated, coaches are often volunteers, and the organization and administration of the club is determined by the club officers" (The National Intramural Sports Association, 2008, p. 170).

Emphasis is placed on student leadership and participation. Involvement in the club should "provide a learning experience for the members." (p. 170).

Sport club president: The role of president is described in this institution's sport club manual as "student leaders who are responsible for administering club meetings, supervising all club events (home and away) and ensuring compliance of the club with all 
campus, local, state, and federal regulations, among other duties" (James Madison University, 2012, p. 6). In the present study, the presidents of the sport clubs were referred to alternatively as presidents and study participants.

Student involvement: An involved student is one who "devotes considerable energy to academics, spends a great deal of time on campus, participates actively in student organizations and activities and interacts often with faculty" (Astin, 1984, p. 297). The term involvement, as defined by Astin, is the "amount of physical and psychological energy that students devote to the educational experience in college" (p. 297).

Student development: Student development is "the ways that a student grows, progresses, or increases his or her development capabilities as a result of enrollment in an institution of higher education" (Rodgers, 1990, p. 27). Development should not be confused with learning. Development is a not necessarily related to academic achievement but rather a function of the quality of efforts students invest in their college community (Pascarella, 1985). In addition, development should not be confused with change or growth. Both change and growth can happen positively or negatively; development is only seen as positive or favorable growth (Evans, Forney, Guido, Patton, \& Renn, 2009).

Sport club council: The Sport Club Council (SCC) as "an association of student leaders representing the recognized sport clubs of James Madison University. The mission of the SCC is to govern and promote both competitive and non-competitive recreational opportunities for undergraduate and graduate students who chose to participate in the sport club program...the SCC seeks to accomplish this by providing 
administrative, representative, financial and judicial support to those organizations recognized by the SCC" (James Madison University Recreation).

\section{Overview of Chapters}

Chapter Two describes literature related to student development, campus recreation, and sport clubs. Chapter Three provides a description of the methodology, explanation of data analysis, and trustworthiness of the study. Chapter Four shares the results constructed from the data, a discussion and recommendations for practice. Chapter Five describes conclusions of the study and recommendations for future research. 


\section{Chapter 2: Review of the Literature}

The literature on student development and involvement, campus recreation, and sport clubs emphasized that students who were more involved gained more from his or her college experience. There was limited data describing the experiences of volunteer leaders in campus recreation and specifically sport club presidents. The literature was mostly quantitative in nature and sampled members of the clubs, not the leaders. If insight could have been gained into how sport club presidents described their experience, perceived their development, and how their involvement affected their college experience, sport club programs and campus recreation departments could be viewed as a learning laboratory and a place where learning occurs. In the following review, student out of class experiences were related to gains in student development and involvement and both physical and psychological involvement was related to persistence in college and academic success. The contents of the tables are described below.

\section{Student Development}

Researchers found differences in academic success (GPA), psychosocial development, and health status between those who participated in student organizations and those who did not (Abrahamowicz, 1988; Becker, Cooper, Atkins, \& Martin, 2009; Foubert \& Grainger, 2006). Also, the literature revealed that peers significantly influenced how students spent their time and what students did in college (Kuh, $\mathrm{Hu}, \&$ Vesper, 2000). The environment, individual differences, and peer influences were variables that influenced development. Studies involving the investigation of student outcomes due to involvement and the literature mentioned above are reviewed in Table 1. 


\section{Campus Recreation}

Campus recreation departments were one way students were involved on the college campus. Participation in campus recreation was positively correlated to a student's overall, health, interest in staying fit, fitness level, well-being, and stress management (Henchy, 2011). Hackett (2007) also found a positive correlation between employment in campus recreation and academic success. Studies that explored campus recreation's role in student development are presented in Table 2.

\section{Sport Clubs}

The literature review on sport clubs is presented in Table 3. Most of this literature was quantitative in nature and assessed many participants, not sport club leaders. The literature demonstrates that through participation in sport clubs, participants acquired specific skills from their involvement and their membership enhanced their college experience (Weis, 2007). 
Table 1.

Student Development and Involvement

\begin{tabular}{|c|c|c|c|c|c|}
\hline Title/Authors & Purpose & Participants & Instruments & Procedures & Results \\
\hline $\begin{array}{l}\text { College } \\
\text { involvement, } \\
\text { perceptions and } \\
\text { satisfaction: A } \\
\text { study of } \\
\text { memberships in } \\
\text { student } \\
\text { organizations } \\
\text { (Abrahamowicz, } \\
\text { 1988) }\end{array}$ & $\begin{array}{l}\text { To explore the } \\
\text { relationship that } \\
\text { participation in } \\
\text { student } \\
\text { organizations } \\
\text { have with } \\
\text { encouraging } \\
\text { broader } \\
\text { involvement in } \\
\text { the institution, } \\
\text { satisfaction with } \\
\text { the college } \\
\text { experience, and } \\
\text { perceptions of } \\
\text { college. }\end{array}$ & $\begin{array}{l}151 \text { students } \\
\text { involved in } 40 \\
\text { organizations } \\
\text { and } 192 \\
\text { students who } \\
\text { are not } \\
\text { involved in any } \\
\text { organization. }\end{array}$ & $\begin{array}{l}\text { College student } \\
\text { experiences } \\
\text { questionnaire } \\
\text { (CSE), this } \\
\text { focuses on what } \\
\text { students do in } \\
\text { college and } \\
\text { what conditions } \\
\text { in college have } \\
\text { an influence on } \\
\text { them. The } \\
\text { largest section, } \\
\text { the quality of } \\
\text { effort scales, } \\
\text { asks students } \\
\text { how they use } \\
\text { opportunities } \\
\text { for learning } \\
\text { available in } \\
\text { college. }\end{array}$ & $\begin{array}{l}\text { The instrument } \\
\text { was } \\
\text { administered to } \\
550 \\
\text { undergraduate } \\
\text { students of a } \\
\text { large commuter } \\
\text { university. }\end{array}$ & $\begin{array}{l}\text { Members scored } \\
\text { significantly higher } \\
\text { (more positive } \\
\text { outcomes) on all } 14 \\
\text { college activities } \\
\text { categories. } \\
\text { Involvement in } \\
\text { student organizations } \\
\text { can lead to more } \\
\text { involvement in other } \\
\text { domains outside of the } \\
\text { particular } \\
\text { organization. }\end{array}$ \\
\hline
\end{tabular}




\begin{tabular}{|c|c|c|c|c|c|}
\hline Title/Authors & Purpose & Participants & Instruments & Procedures & Results \\
\hline $\begin{array}{l}\text { What helps } \\
\text { students thrive? } \\
\text { An investigation } \\
\text { of student } \\
\text { engagement and } \\
\text { performance } \\
\\
\text { (Becker, Cooper, } \\
\text { Atkins, \& } \\
\text { Martin, 2009) }\end{array}$ & $\begin{array}{l}\text { To discover what } \\
\text { helps students } \\
\text { thrive, not just } \\
\text { survive at school. } \\
\text { To investigate } \\
\text { the relationship } \\
\text { between student } \\
\text { involvement in } \\
\text { student affairs } \\
\text { functions and } \\
\text { student success. }\end{array}$ & 691 students & $\begin{array}{l}\text { The } \\
\text { questionnaire } \\
\text { measured } \\
\text { behaviors, } \\
\text { status and } \\
\text { personal } \\
\text { information as } \\
\text { well as a health } \\
\text { scale } \\
\text { (Salutogenic } \\
\text { Wellness } \\
\text { Promotion } \\
\text { Scale, a 7- } \\
\text { dimensional, } 26 \\
\text { item } \\
\text { questionnaire). } \\
\text { It assesses } \\
\text { behaviors in the } \\
\text { physical, social, } \\
\text { emotional, } \\
\text { spiritual, } \\
\text { intellectual, } \\
\text { vocational and } \\
\text { environmental } \\
\text { areas of life. }\end{array}$ & $\begin{array}{l}\text { Participants } \\
\text { completed the } \\
\text { questionnaire } \\
\text { and Wellness } \\
\text { Scale. }\end{array}$ & $\begin{array}{l}\text { The more involved } \\
\text { with student affairs } \\
\text { programs, the more } \\
\text { successful they are, } \\
\text { when success is } \\
\text { measured by GPA and } \\
\text { health status. This } \\
\text { study affirms that } \\
\text { student affairs } \\
\text { programs can have an } \\
\text { impact on student } \\
\text { success. }\end{array}$ \\
\hline
\end{tabular}




\begin{tabular}{|c|c|c|c|c|c|}
\hline Title/Authors & Purpose & Participants & Instruments & Procedures & Results \\
\hline $\begin{array}{l}\text { Why } \\
\text { involvement } \\
\text { matters: A } \\
\text { review of } \\
\text { research on } \\
\text { student } \\
\text { involvement in } \\
\text { the collegiate } \\
\text { setting } \\
\\
\text { (Moore, Lovell, } \\
\text { McGann, \& } \\
\text { Wyrick, 1998) }\end{array}$ & $\begin{array}{l}\text { A review that } \\
\text { highlights } \\
\text { different types of } \\
\text { student } \\
\text { involvement, } \\
\text { summarizes key } \\
\text { findings, and } \\
\text { identifies } \\
\text { significant gaps } \\
\text { in the research. }\end{array}$ & N/A & N/A & N/A & $\begin{array}{l}\text { Student affairs } \\
\text { administrators need to } \\
\text { continue the } \\
\text { exploration on the } \\
\text { importance of college } \\
\text { student involvement. } \\
\text { In order to ensure } \\
\text { resources are available } \\
\text { to support programs } \\
\text { and activities that } \\
\text { promote involvement, } \\
\text { the body of literature } \\
\text { regarding student } \\
\text { involvement needs to } \\
\text { continuously be } \\
\text { developed and } \\
\text { utilized. This will } \\
\text { serve as a factor to } \\
\text { how universities } \\
\text { approach program } \\
\text { development, } \\
\text { assessment, and } \\
\text { budgeting issues. }\end{array}$ \\
\hline
\end{tabular}




\begin{tabular}{|c|c|c|c|c|c|}
\hline Title/Authors & Purpose & Participants & Instruments & Procedures & Results \\
\hline $\begin{array}{l}\text { Students' } \\
\text { experiences and } \\
\text { outcomes from } \\
\text { participation in } \\
\text { an } \\
\text { extracurricular } \\
\text { club } \\
\text { (Carruthers, } \\
\text { Busser, Cain, \& } \\
\text { Brown, 2010) }\end{array}$ & $\begin{array}{l}\text { Understand } \\
\text { students' } \\
\text { experiences and } \\
\text { outcomes from } \\
\text { participation in } \\
\text { an } \\
\text { extracurricular } \\
\text { club. }\end{array}$ & $\begin{array}{l}11 \text { students } \\
\text { who were } \\
\text { members of the } \\
\text { Professional } \\
\text { Golf } \\
\text { Management } \\
\text { Student } \\
\text { Association, } \\
\text { with varying } \\
\text { level of } \\
\text { involvement. } \\
\text { Two of the } \\
\text { students were } \\
\text { female and nine } \\
\text { male. }\end{array}$ & $\begin{array}{l}\text { Semi-structured } \\
\text { interviews }\end{array}$ & $\begin{array}{l}\text { Semi-structured } \\
\text { interviews lasted } \\
\text { approximately } \\
45-90 \text { minutes } \\
\text { long }\end{array}$ & $\begin{array}{l}\text { Four themes emerged } \\
\text { based on the students' } \\
\text { perspective of the } \\
\text { outcomes of their } \\
\text { experience: } \\
\text { relatedness, self- } \\
\text { determination/empow } \\
\text { erment, competence } \\
\text { and fun. }\end{array}$ \\
\hline Title/Authors & Purpose & Participants & Instruments & Procedures & Results \\
\hline $\begin{array}{l}\text { Developing } \\
\text { leadership } \\
\text { potential through } \\
\text { student activities } \\
\text { and } \\
\text { organizations } \\
\text { (Guido-DiBrito } \\
\text { \& Batchelor, } \\
\text { 1988) }\end{array}$ & $\begin{array}{l}\text { To investigate } \\
\text { college student } \\
\text { perceptions of } \\
\text { leadership and } \\
\text { beliefs that } \\
\text { empowers } \\
\text { students and } \\
\text { constrains from } \\
\text { involvement in } \\
\text { leadership. }\end{array}$ & $\begin{array}{l}24 \text { student } \\
\text { leaders and } 5 \\
\text { disengaged } \\
\text { students }\end{array}$ & $\begin{array}{l}\text { Semi structured } \\
\text { interview } \\
\text { protocol, as } \\
\text { well as written } \\
\text { definitions of } \\
\text { leadership } \\
\text { provided by the } \\
\text { participants }\end{array}$ & $\begin{array}{l}\text { Five focus } \\
\text { groups were } \\
\text { conducted for } \\
\text { engaged } \\
\text { students and } \\
\text { interviews were } \\
\text { conducted for } \\
\text { the disengaged } \\
\text { students. }\end{array}$ & $\begin{array}{l}\text { Students had an } \\
\text { industrial perspective } \\
\text { on leadership, as did } \\
\text { much of the } \\
\text { programming at the } \\
\text { institution. The } \\
\text { environment, } \\
\text { therefore, may } \\
\text { influence perceptions } \\
\text { of leadership. }\end{array}$ \\
\hline
\end{tabular}




\begin{tabular}{|c|c|c|c|c|c|}
\hline Title/Authors & Purpose & Participants & Instruments & Procedures & Results \\
\hline $\begin{array}{l}\text { Effects of } \\
\text { involvement in } \\
\text { clubs and } \\
\text { organizations on } \\
\text { the psychosocial } \\
\text { development of } \\
\text { first-year and } \\
\text { senior college } \\
\text { students } \\
\text { (Foubert \& } \\
\text { Grainger, 2006) }\end{array}$ & $\begin{array}{l}\text { To what extent } \\
\text { do varying levels } \\
\text { of involvement } \\
\text { in student clubs } \\
\text { and } \\
\text { organizations } \\
\text { coincide with the } \\
\text { development of } \\
\text { students at the } \\
\text { beginning of } \\
\text { their sophomore } \\
\text { year and the end } \\
\text { of their senior } \\
\text { year along three } \\
\text { of Chickering's } \\
\text { and Reissner's } \\
\text { vectors. }\end{array}$ & $\begin{array}{l}\text { College aged } \\
\text { students ( } 18- \\
22), 40 \% \text { men, } \\
60 \% \text { women, } \\
307 \text { students } \\
\text { total }\end{array}$ & $\begin{array}{l}\text { SDTLI (survey } \\
\text { instrument } \\
\text { based on } \\
\text { Chickering and } \\
\text { Reissner's } \\
\text { vectors), } \\
\text { measures } \\
\text { development on } \\
3 \text { of the vectors }\end{array}$ & $\begin{array}{l}\text { A sample of } 600 \\
\text { incoming } \\
\text { freshman } \\
\text { students were } \\
\text { recruited to } \\
\text { participate. They } \\
\text { completed the } \\
\text { instrument at the } \\
\text { beginning of } \\
\text { their sophomore } \\
\text { year and end of } \\
\text { senior year. }\end{array}$ & $\begin{array}{l}\text { A higher level of } \\
\text { involvement in student } \\
\text { organization is } \\
\text { connected to } \\
\text { psychosocial } \\
\text { development. Students } \\
\text { who are involved in } \\
\text { organizations during } \\
\text { their college } \\
\text { experience are also } \\
\text { those who } \\
\text { demonstrate higher } \\
\text { levels of development } \\
\text { in many areas. } \\
\text { Particularly, on } \\
\text { students establishing } \\
\text { and clarifying } \\
\text { purpose, educational } \\
\text { involvement, career } \\
\text { planning, life } \\
\text { management and } \\
\text { cultural participation. }\end{array}$ \\
\hline
\end{tabular}




\begin{tabular}{|c|c|c|c|c|c|}
\hline Title/Authors & Purpose & Participants & Instruments & Procedures & Results \\
\hline $\begin{array}{l}\text { Student } \\
\text { development } \\
\text { through } \\
\text { involvement: } \\
\text { Specific changes } \\
\text { over time }\end{array}$ & $\begin{array}{l}\text { Examined the } \\
\text { ways in which } \\
\text { students who are } \\
\text { involved in } \\
\text { student } \\
\text { organizations } \\
\text { and leadership } \\
\text { positions change } \\
\text { while in college. }\end{array}$ & $\begin{array}{l}\text { First time, } \\
\text { traditional age, } \\
\text { entering } \\
\text { freshmen at a } \\
\text { doctoral-level } \\
\text { institution of } \\
12,000 \\
\text { students. } 1,193 \\
\text { students } \\
\text { participated in } \\
\text { the survey. }\end{array}$ & $\begin{array}{l}\text { The student } \\
\text { developmental } \\
\text { task and } \\
\text { lifestyle } \\
\text { inventory, an } \\
\text { instrument that } \\
\text { measures } \\
\text { various aspects } \\
\text { of college } \\
\text { student } \\
\text { development. } \\
\text { This instrument } \\
\text { is based on } \\
\text { Chickering's } \\
\text { theory of } \\
\text { development. }\end{array}$ & $\begin{array}{l}\text { Participants } \\
\text { were given the } \\
\text { SDTLI their } \\
\text { freshman year } \\
\text { and again in a } \\
\text { follow up study. } \\
\text { In the follow up, } \\
\text { they completed a } \\
\text { questionnaire } \\
\text { about their usage } \\
\text { of programs and } \\
\text { services on } \\
\text { campus and } \\
\text { were interview } \\
\text { scores were } \\
\text { compared. }\end{array}$ & $\begin{array}{l}\text { Leadership roles } \\
\text { appear to provide the } \\
\text { opportunity to sustain } \\
\text { and further } \\
\text { developmental skills. } \\
\text { Involvement is related } \\
\text { to change in college. } \\
\text { The changes occur } \\
\text { through both informal } \\
\text { and formal activities. } \\
\text { Involvement in } \\
\text { student organizations } \\
\text { appears to have } \\
\text { positive effects on the } \\
\text { student's total } \\
\text { academic experience. }\end{array}$ \\
\hline Title/Authors & Purpose & Participants & Instruments & Procedures & Results \\
\hline $\begin{array}{l}\text { They shall be } \\
\text { known by what } \\
\text { they do: An } \\
\text { activities based } \\
\text { typology of } \\
\text { college students } \\
\text { (Kuh, Hu, \& } \\
\text { Vesper, 2000) }\end{array}$ & $\begin{array}{l}\text { To classify } \\
\text { students } \\
\text { reference groups } \\
\text { based on the } \\
\text { activities in } \\
\text { which the } \\
\text { student is } \\
\text { engaged. }\end{array}$ & $\begin{array}{l}51,155 \text { full- } \\
\text { time enrolled } \\
\text { undergraduate } \\
\text { students } \\
\text { between } 1990- \\
1997 \text { at } 128 \\
\text { different } \\
\text { institutions }\end{array}$ & $\begin{array}{l}\text { College Student } \\
\text { Experiences } \\
\text { Questionnaire } \\
\text { which requires } \\
\text { students to } \\
\text { reflect on what } \\
\text { they are gaining } \\
\text { out of college. }\end{array}$ & $\begin{array}{l}\text { Students were } \\
\text { administered the } \\
\text { survey. }\end{array}$ & $\begin{array}{l}\text { Peers significantly } \\
\text { influence how } \\
\text { students spend their } \\
\text { time and what } \\
\text { students do in college } \\
\text { directly affects what } \\
\text { they gain. }\end{array}$ \\
\hline
\end{tabular}




\begin{tabular}{|c|c|c|c|c|c|}
\hline Title/Authors & Purpose & Participants & Instruments & Procedures & Results \\
\hline $\begin{array}{l}\text { Assessing what } \\
\text { really matters to } \\
\text { student learning }\end{array}$ & $\begin{array}{l}\text { State legislators, } \\
\text { accreditors, } \\
\text { parents, } \\
\text { employers and } \\
\text { others wanted to } \\
\text { know what } \\
\text { students are } \\
\text { learning and } \\
\text { what they can } \\
\text { do. The National } \\
\text { Survey of } \\
\text { Student } \\
\text { Engagement } \\
\text { (NSSE) was } \\
\text { created in order } \\
\text { to discover this } \\
\text { information. }\end{array}$ & N/A & N/A & N/A & $\begin{array}{l}\text { The NSSE provides } \\
\text { information that every } \\
\text { school needs in order } \\
\text { to focus its efforts to } \\
\text { improve the } \\
\text { undergraduate } \\
\text { experience. Five } \\
\text { benchmarks of } \\
\text { effective educational } \\
\text { practice were created } \\
\text { which include: student } \\
\text { interaction with } \\
\text { faculty members, } \\
\text { enriching educational } \\
\text { experiences, level of } \\
\text { academic challenge, } \\
\text { active and } \\
\text { collaborative learning } \\
\text { and supportive } \\
\text { campus environment. }\end{array}$ \\
\hline
\end{tabular}




\begin{tabular}{|c|c|c|c|c|c|}
\hline Title/Authors & Purpose & Participants & Instruments & Procedures & Results \\
\hline $\begin{array}{l}\text { Student } \\
\text { governance: A } \\
\text { qualitative study } \\
\text { of leadership in } \\
\text { a Student } \\
\text { Government } \\
\text { Association } \\
\text { (May, 2009) }\end{array}$ & $\begin{array}{l}\text { Explores the } \\
\text { experiences of } \\
\text { individual } \\
\text { college students } \\
\text { who held } \\
\text { presidency in } \\
\text { student } \\
\text { governance. }\end{array}$ & $\begin{array}{l}\text { Six participants } \\
\text { who served as } \\
\text { the president of } \\
\text { student } \\
\text { government. }\end{array}$ & $\begin{array}{l}\text { Journals (for } \\
\text { eight weeks } \\
\text { every other } \\
\text { week for a total } \\
\text { of four entries), } \\
\text { interviews and } \\
\text { follow-up } \\
\text { interviews }\end{array}$ & $\begin{array}{l}\text { Each participant } \\
\text { engaged in two } \\
45-90 \text { minute } \\
\text { interviews }\end{array}$ & $\begin{array}{l}\text { Several themes } \\
\text { regarding the } \\
\text { participant's } \\
\text { experience emerged: } \\
\text { positive and negative } \\
\text { facets of their } \\
\text { presidencies, stress, } \\
\text { finding balance, } \\
\text { interpersonal } \\
\text { relationships, personal } \\
\text { characteristics of a } \\
\text { leader and the roles of } \\
\text { the student } \\
\text { government president. }\end{array}$ \\
\hline $\begin{array}{l}\text { Student } \\
\text { involvement: A } \\
\text { developmental } \\
\text { theory for } \\
\text { Higher } \\
\text { Education } \\
\text { (Astin, 1984) }\end{array}$ & $\begin{array}{l}\text { According to } \\
\text { Theory of } \\
\text { Involvement, the } \\
\text { extent to which } \\
\text { students can } \\
\text { achieve } \\
\text { particular } \\
\text { developmental } \\
\text { goals is a } \\
\text { function of the } \\
\text { time and effort } \\
\text { they devote to } \\
\text { activities. }\end{array}$ & N/A & N/A & $\begin{array}{l}\text { Literature } \\
\text { review; this is an } \\
\text { explanation of a } \\
\text { theory and } \\
\text { longitudinal } \\
\text { studies from the } \\
\text { past. }\end{array}$ & $\begin{array}{l}\text { Institutional policies } \\
\text { and practices can be } \\
\text { evaluated by the } \\
\text { degree they increase } \\
\text { or reduce student } \\
\text { involvement. Astin } \\
\text { suggests future } \\
\text { research focus on } \\
\text { types of involvement } \\
\text { and student } \\
\text { development } \\
\text { outcomes related to } \\
\text { other theorists. }\end{array}$ \\
\hline
\end{tabular}




\begin{tabular}{|c|c|c|c|c|c|}
\hline Title/Authors & Purpose & Participants & Instruments & Procedures & Results \\
\hline $\begin{array}{l}\text { In their own } \\
\text { words: What } \\
\text { students learn } \\
\text { outside the } \\
\text { classroom } \\
\text { (Kuh 1993, } \\
\text { 1995) }\end{array}$ & $\begin{array}{l}\text { To discover, by } \\
\text { asking } \\
\text { undergrads to } \\
\text { reflect on their } \\
\text { college years, the } \\
\text { out-of-class } \\
\text { experiences on } \\
\text { their learning } \\
\text { and personal } \\
\text { development. }\end{array}$ & $\begin{array}{l}\text { 194 college } \\
\text { seniors from } 12 \\
\text { different } \\
\text { institutions, } \\
\text { institution was } \\
\text { selected for the } \\
\text { rich out-of- } \\
\text { class learning } \\
\text { and personal } \\
\text { development } \\
\text { opportunities. }\end{array}$ & $\begin{array}{l}\text { Semi structured } \\
\text { interviews. }\end{array}$ & $\begin{array}{l}\text { Interviews were } \\
\text { conducted } \\
\text { between January } \\
\text { and June of } \\
1989 \text { by eight } \\
\text { people. The } \\
\text { interviews } \\
\text { occurred in } \\
\text { private rooms in } \\
\text { campus } \\
\text { buildings. }\end{array}$ & $\begin{array}{l}\text { Experiences beyond } \\
\text { the classroom } \\
\text { contribute to student } \\
\text { learning and personal } \\
\text { development. } \\
\text { Knowledge } \\
\text { acquisition is most } \\
\text { frequently associated } \\
\text { with in classroom } \\
\text { learning. Student } \\
\text { background } \\
\text { characteristics were } \\
\text { unrelated to outcomes. } \\
\text { Institution was related } \\
\text { to differences in } \\
\text { outcomes. }\end{array}$ \\
\hline Title/Authors & Purpose & Participants & Instruments & Procedures & Results \\
\hline $\begin{array}{l}\text { Developing } \\
\text { leadership } \\
\text { capacity in } \\
\text { college students: } \\
\text { Findings from a } \\
\text { national study } \\
\text { (Dugan \& } \\
\text { Komives, 2007) }\end{array}$ & $\begin{array}{l}\text { The MSL } \\
\text { Research team } \\
\text { was interested in } \\
\text { aspects of } \\
\text { students' } \\
\text { experiences in } \\
\text { college that } \\
\text { contributed to } \\
\text { leadership } \\
\text { outcomes. }\end{array}$ & $\begin{array}{l}52 \text { campuses } \\
\text { were sampled } \\
\text { andApproximat } \\
\text { ely } 50,000 \\
\text { completed the } \\
\text { survey. }\end{array}$ & $\begin{array}{l}\text { Socially } \\
\text { Responsible } \\
\text { Leadership } \\
\text { Scale and a } \\
\text { Leadership } \\
\text { Efficacy Scale. }\end{array}$ & $\begin{array}{l}\text { The survey was } \\
\text { administered to } \\
\text { over } 63,000 \\
\text { students, which } \\
\text { included a } \\
\text { demographics } \\
\text { questionnaire. }\end{array}$ & $\begin{array}{l}\text { Ten recommendations } \\
\text { to enrich campus } \\
\text { leadership programs } \\
\text { were found including: } \\
\text { discuss sociocultural } \\
\text { issues and get students } \\
\text { involved. }\end{array}$ \\
\hline
\end{tabular}


Table 2.

Campus Recreation

\begin{tabular}{|c|c|c|c|c|c|}
\hline Title/Authors & Purpose & Participants & Instruments & Procedures & Results \\
\hline $\begin{array}{l}\text { Influence of } \\
\text { campus } \\
\text { recreation } \\
\text { beyond the gym } \\
\text { (Henchy, 2011) }\end{array}$ & $\begin{array}{l}\text { To examine ways } \\
\text { in which campus } \\
\text { recreation } \\
\text { facilities and } \\
\text { programs } \\
\text { positively } \\
\text { influence } \\
\text { students' lives. } \\
\text { To examine the } \\
\text { influence of } \\
\text { campus } \\
\text { recreation on } \\
\text { recruitment and } \\
\text { retention as well } \\
\text { as the social and } \\
\text { health benefits } \\
\text { for students of } \\
\text { campus } \\
\text { recreation. }\end{array}$ & $\begin{array}{l}2,500 \text { students } \\
\text { at a } \\
\text { southeastern } \\
\text { university were } \\
\text { randomly } \\
\text { selected to } \\
\text { complete the } \\
\text { survey. } 237 \\
\text { students } \\
\text { completed the } \\
\text { survey. }\end{array}$ & $\begin{array}{l}\text { Survey was } \\
\text { based upon the } \\
\text { NIRSA Voice } \\
\text { Campus } \\
\text { Recreation } \\
\text { Impact Study. } \\
\text { Addressed } \\
\text { questions } \\
\text { involving } \\
\text { recruitment, } \\
\text { retention, } \\
\text { satisfaction, } \\
\text { involvement, } \\
\text { and benefits. } \\
\text { Both multiple- } \\
\text { choice and } \\
\text { open-ended } \\
\text { items were } \\
\text { used. }\end{array}$ & $\begin{array}{l}\text { Survey } \\
\text { administered to } \\
237 \text { students } \\
\text { who completed. }\end{array}$ & $\begin{array}{l}\text { Participating in } \\
\text { campus recreation } \\
\text { positively influenced a } \\
\text { variety of areas of } \\
\text { students' lives } \\
\text { including: overall } \\
\text { health, interest in } \\
\text { staying fit, fitness } \\
\text { level, well-being and } \\
\text { stress management. } \\
\text { Campus recreation } \\
\text { facilities help students } \\
\text { lead healthier lives. }\end{array}$ \\
\hline
\end{tabular}




\begin{tabular}{|c|c|c|c|c|c|}
\hline Title/Authors & Purpose & Participants & Instruments & Procedures & Results \\
\hline $\begin{array}{l}\text { Best practices in } \\
\text { student } \\
\text { development for } \\
\text { campus } \\
\text { recreation } \\
\text { professionals } \\
\text { (Toperzer, } \\
\text { Anderson, \& } \\
\text { Barcelona, } \\
\text { 2011) }\end{array}$ & $\begin{array}{l}\text { To identify best } \\
\text { practices for } \\
\text { effective student } \\
\text { development in } \\
\text { campus } \\
\text { recreation } \\
\text { programs } \\
\text { affiliated with } \\
\text { the NIRSA. }\end{array}$ & $\begin{array}{l}\text { Expert panel of } \\
\text { five of the } 2009 \\
\text { Regional Vice- } \\
\text { Presidents of } \\
\text { the NIRSA. }\end{array}$ & $\begin{array}{l}\text { Four rounds of } \\
\text { the Delphi } \\
\text { method were } \\
\text { conducted. }\end{array}$ & $\begin{array}{l}\text { Relied on a } \\
\text { panel of experts } \\
\text { to obtain input } \\
\text { on a } \\
\text { predetermined } \\
\text { topic, this topic } \\
\text { was information } \\
\text { regarding } \\
\text { practices to } \\
\text { promote student } \\
\text { development } \\
\text { among } \\
\text { employees. }\end{array}$ & $\begin{array}{l}\text { Greater understanding } \\
\text { of how campus } \\
\text { recreation might } \\
\text { facilitate student } \\
\text { development through } \\
\text { compiling a database } \\
\text { of best practices. }\end{array}$ \\
\hline Title/Authors & Purpose & Participants & Instruments & Procedures & Results \\
\hline $\begin{array}{l}\text { Exploring the } \\
\text { relationship } \\
\text { between } \\
\text { recreational } \\
\text { sports } \\
\text { employment and } \\
\text { academic } \\
\text { success } \\
\text { (Hackett, 2007) }\end{array}$ & $\begin{array}{l}\text { Examined the } \\
\text { relationship } \\
\text { between part- } \\
\text { time student } \\
\text { employment in } \\
\text { recreational } \\
\text { sports and } \\
\text { academic } \\
\text { success. }\end{array}$ & $\begin{array}{l}330 \\
\text { undergraduate } \\
\text { recreational } \\
\text { sports student } \\
\text { employees were } \\
\text { compared to } \\
\text { those not } \\
\text { employed by } \\
\text { recreational } \\
\text { sports (350) }\end{array}$ & $\begin{array}{l}\text { A record of } \\
\text { employment } \\
\text { history and } \\
\text { GPA. }\end{array}$ & $\begin{array}{l}\text { The student staff } \\
\text { was compared to } \\
\text { the general } \\
\text { body. The } \\
\text { registrar's office } \\
\text { provided a data } \\
\text { matrix including } \\
\text { gender, year in } \\
\text { school, spring } \\
\text { semester GPA, } \\
\text { and spring credit } \\
\text { hours enrolled. }\end{array}$ & $\begin{array}{l}\text { Positive correlation } \\
\text { between employment } \\
\text { and academic success. }\end{array}$ \\
\hline
\end{tabular}




\begin{tabular}{|c|c|c|c|c|c|}
\hline Title/Authors & Purpose & Participants & Instruments & Procedures & Results \\
\hline $\begin{array}{l}\text { The } \\
\text { development of } \\
\text { an instrument to } \\
\text { measure } \\
\text { effectiveness in } \\
\text { campus } \\
\text { receation } \\
\text { programs } \\
\text { (Weese, 1997) }\end{array}$ & $\begin{array}{l}\text { Examined the } \\
\text { quality and } \\
\text { effectiveness of } \\
\text { campus } \\
\text { recreational } \\
\text { structure. This } \\
\text { study will use the } \\
\text { Satisfaction } \\
\text { Index to uncover } \\
\text { perceptual } \\
\text { information of } \\
\text { satisfaction. }\end{array}$ & N/A & $\begin{array}{l}\text { Target } \\
\text { population } \\
\text { Satisfaction } \\
\text { Index is an } \\
\text { instrument to } \\
\text { measure } \\
\text { organizational } \\
\text { effectiveness in } \\
\text { campus } \\
\text { recreational } \\
\text { sports } \\
\text { programs. }\end{array}$ & $\begin{array}{l}\text { The content for } \\
\text { the index was } \\
\text { drawn from } \\
\text { literature on } \\
\text { organizational } \\
\text { effectiveness } \\
\text { and campus } \\
\text { recreation. } 15 \\
\text { our of } 25 \text { items } \\
\text { constructed was } \\
\text { voted on by ten } \\
\text { NIRSA leaders. }\end{array}$ & $\begin{array}{l}\text { Campus recreation } \\
\text { professionals need to } \\
\text { be more involved in } \\
\text { measuring the quality } \\
\text { of their programs. }\end{array}$ \\
\hline Title/Authors & Purpose & Participants & Instruments & Procedures & Results \\
\hline $\begin{array}{l}\text { The impact of } \\
\text { recreational } \\
\text { sports on } \\
\text { student } \\
\text { development: A } \\
\text { theoretical } \\
\text { model } \\
\text { (Todaro, 1993) }\end{array}$ & $\begin{array}{l}\text { To describe how } \\
\text { Chickering's } \\
\text { model of student } \\
\text { development can } \\
\text { better explain the } \\
\text { positive impact } \\
\text { that recreation } \\
\text { can have on the } \\
\text { participants. }\end{array}$ & N/A & N/A & $\begin{array}{l}\text { Description of } \\
\text { the theory, this } \\
\text { is a summary of } \\
\text { Chickering's } \\
\text { theoretical } \\
\text { model that } \\
\text { influences } \\
\text { decisions in } \\
\text { campus } \\
\text { recreation. }\end{array}$ & $\begin{array}{l}\text { Recreation contributes } \\
\text { to student } \\
\text { development and } \\
\text { recreation has an } \\
\text { impact on students. } \\
\text { Chickering's model } \\
\text { provides a realistic } \\
\text { framework for } \\
\text { understanding this } \\
\text { positive impact. }\end{array}$ \\
\hline
\end{tabular}




\begin{tabular}{|c|c|c|c|c|c|}
\hline Title/Authors & Purpose & Participants & Instruments & Procedures & Results \\
\hline $\begin{array}{l}\text { Student } \\
\text { involvement in } \\
\text { campus } \\
\text { recreational } \\
\text { sports activities } \\
\text { and gains in } \\
\text { team- } \\
\text { functioning } \\
\text { (Barcelona, } \\
\text { 2002) }\end{array}$ & $\begin{array}{l}\text { Examine the } \\
\text { relationship } \\
\text { between } \\
\text { undergraduate } \\
\text { students' self- } \\
\text { reported gains in } \\
\text { their ability to } \\
\text { function as a } \\
\text { team member } \\
\text { and involvement } \\
\text { in four areas of } \\
\text { student life: a) } \\
\text { art, music and } \\
\text { theater; b) } \\
\text { recreational sport } \\
\text { programs and } \\
\text { facilities; c) } \\
\text { clubs and student } \\
\text { organizations; d) } \\
\text { student union } \\
\text { activities. }\end{array}$ & $\begin{array}{l}\text { Juniors and } \\
\text { seniors from } \\
314 \text { colleges } \\
\text { and universities } \\
\text { between 1990- } \\
1998 \text {. }\end{array}$ & $\begin{array}{l}\text { The third } \\
\text { edition of the } \\
\text { College } \\
\text { Student- } \\
\text { Experiences } \\
\text { Questionnaire } \\
\text { (CSEQ) in } \\
\text { order to } \\
\text { measure } \\
\text { frequency of } \\
\text { student } \\
\text { involvement in } \\
\text { a number of } \\
\text { activities } \\
\text { associated with } \\
\text { the college } \\
\text { experience and } \\
\text { to measure the } \\
\text { gains that } \\
\text { students feel } \\
\text { they derive } \\
\text { from attending } \\
\text { college. }\end{array}$ & $\begin{array}{l}\text { Participants took } \\
\text { the survey by } \\
\text { reflecting on } \\
\text { how much they } \\
\text { gained various } \\
\text { areas through } \\
\text { their } \\
\text { involvement in } \\
\text { college. }\end{array}$ & $\begin{array}{l}\text { Involvement in } \\
\text { recreational sport } \\
\text { programs and facilities } \\
\text { and clubs and student } \\
\text { organizations were } \\
\text { significant predictors } \\
\text { of gains in team } \\
\text { functioning, with } \\
\text { involvement in } \\
\text { recreational programs } \\
\text { and facilities being the } \\
\text { strongest predictor. }\end{array}$ \\
\hline
\end{tabular}




\begin{tabular}{|c|c|c|c|c|c|}
\hline Title/Authors & Purpose & Participants & Instruments & Procedures & Results \\
\hline $\begin{array}{l}\text { Value of } \\
\text { Recreational } \\
\text { Sports on } \\
\text { College } \\
\text { Campuses } \\
\\
\text { (NIRSA, 2002) }\end{array}$ & $\begin{array}{l}\text { To examine the } \\
\text { value and } \\
\text { contribution of } \\
\text { recreational } \\
\text { sports to } \\
\text { participants' } \\
\text { lives and to } \\
\text { document the } \\
\text { buying power of } \\
\text { participants of } \\
\text { recreational } \\
\text { sports. }\end{array}$ & $\begin{array}{l}2,673 \\
\text { interviews were } \\
\text { completed } \\
\text { across sixteen } \\
\text { campuses. }\end{array}$ & $\begin{array}{l}\text { Interviews were } \\
\text { conducted with } \\
\text { students on } \\
\text { campus. }\end{array}$ & $\begin{array}{l}\text { In order to } \\
\text { ensure that the } \\
\text { students were a } \\
\text { representation of } \\
\text { the college, the } \\
\text { goal was to } \\
\text { designate six to } \\
\text { ten points on } \\
\text { each campus } \\
\text { that would give } \\
\text { the interviewers } \\
\text { exposure to a } \\
\text { representative } \\
\text { mix of students. }\end{array}$ & $\begin{array}{l}\text { A correlation was } \\
\text { discovered between } \\
\text { the following benefits: } \\
\text { emotional well-being } \\
\text { improved, improved } \\
\text { happiness and self- } \\
\text { confidence, improved } \\
\text { interaction with } \\
\text { diverse sets of people, } \\
\text { taught team building } \\
\text { skills, aided in time } \\
\text { management, reduced } \\
\text { stress and improved } \\
\text { leadership skills. }\end{array}$ \\
\hline Title/Authors & Purpose & Participants & Instruments & \begin{tabular}{|l} 
Procedures \\
\end{tabular} & Results \\
\hline $\begin{array}{l}\text { The role of the } \\
\text { campus } \\
\text { recreation } \\
\text { center in } \\
\text { creating a } \\
\text { community }\end{array}$ & $\begin{array}{l}\text { To describe how } \\
\text { the campus } \\
\text { recreation center } \\
\text { can serve as a } \\
\text { place for } \\
\text { education and a } \\
\text { place for students } \\
\text { to meet friends, } \\
\text { hang out and } \\
\text { become part of a } \\
\text { community. }\end{array}$ & N/A & N/A & $\begin{array}{l}\text { Discussion of } \\
\text { the emphasis on } \\
\text { campus } \\
\text { recreation } \\
\text { centers to } \\
\text { promote a sense } \\
\text { of community in } \\
\text { campus } \\
\text { environments. }\end{array}$ & $\begin{array}{l}\text { Campus communities } \\
\text { are becoming more } \\
\text { diverse. Therefore, } \\
\text { administrators need to } \\
\text { provide and promote } \\
\text { more opportunities for } \\
\text { interaction, } \\
\text { collaboration and } \\
\text { unification to develop } \\
\text { a stronger sense of } \\
\text { community. }\end{array}$ \\
\hline
\end{tabular}




\begin{tabular}{|c|c|c|c|c|c|}
\hline Title/Authors & Purpose & Participants & Instruments & Procedures & Results \\
\hline $\begin{array}{l}\text { Universiy } \\
\text { students' } \\
\text { satisfaction and } \\
\text { effectiveness of } \\
\text { campus } \\
\text { recreation } \\
\text { programs }\end{array}$ & $\begin{array}{l}\text { To examine the } \\
\text { relationship } \\
\text { between } \\
\text { effectiveness of } \\
\text { campus } \\
\text { recreation } \\
\text { programs and } \\
\text { participants' } \\
\text { satisfaction. }\end{array}$ & $\begin{array}{l}312 \text { students } \\
\text { from } 14 \\
\text { universities (95 } \\
\text { women, } 217 \\
\text { men) with a } \\
\text { mean age of } \\
21.0 \text { years old. }\end{array}$ & $\begin{array}{l}\text { The Target } \\
\text { Population } \\
\text { Satisfaction } \\
\text { Index (TPSI) } \\
\text { was used to } \\
\text { measure } \\
\text { effectiveness in } \\
\text { campus } \\
\text { recreation } \\
\text { programs, the } \\
\text { Athlete } \\
\text { Satisfaction } \\
\text { Questionnaire } \\
\text { was used to } \\
\text { measure } \\
\text { participants' } \\
\text { satisfaction. }\end{array}$ & $\begin{array}{l}\text { The } 312 \text { students } \\
\text { completed both } \\
\text { of the surveys }\end{array}$ & $\begin{array}{l}\text { These questionnaires } \\
\text { and surveys are valid } \\
\text { instruments of } \\
\text { effectiveness in } \\
\text { campus recreation } \\
\text { programs and five } \\
\text { dimensions of } \\
\text { participant } \\
\text { satisfaction, these } \\
\text { instruments can be } \\
\text { used to measure } \\
\text { effectiveness and } \\
\text { participant satisfaction } \\
\text { in campus recreation. }\end{array}$ \\
\hline Title/Authors & Purpose & Participants & Instruments & \begin{tabular}{|l} 
Procedures \\
\end{tabular} & Results \\
\hline $\begin{array}{l}\text { Undergraduate } \\
\text { student benefits } \\
\text { from university } \\
\text { recreation } \\
\text { (Haines, 2001) }\end{array}$ & $\begin{array}{l}\text { To determine the } \\
\text { benefits that } \\
\text { undergraduate } \\
\text { students gain } \\
\text { from } \\
\text { participation in } \\
\text { university. }\end{array}$ & $\begin{array}{l}347 \text { students at } \\
\text { Ohio State } \\
\text { University. }\end{array}$ & $\begin{array}{l}\text { Quality and } \\
\text { Importance of } \\
\text { Recreational } \\
\text { Services } \\
\text { Survey. }\end{array}$ & $\begin{array}{l}\text { The survey was } \\
\text { administered to } \\
\text { students during } \\
\text { the } 1997-1998 \\
\text { school year. }\end{array}$ & $\begin{array}{l}\text { Students benefited } \\
\text { from campus } \\
\text { recreation in the } \\
\text { following categories: } \\
\text { feeling of physical } \\
\text { well-being, sense of } \\
\text { accomplishment, } \\
\text { fitness, and physical } \\
\text { strength. }\end{array}$ \\
\hline
\end{tabular}


Table 3.

\begin{tabular}{|c|c|c|c|c|c|}
\hline Title/Authors & Purpose & Participants & Instruments & Procedures & Results \\
\hline $\begin{array}{l}\text { Club sports: } \\
\text { Maximizing } \\
\text { Positive } \\
\text { outcomes and } \\
\text { minimizing risks } \\
\\
\text { (Lifschutz, } \\
\text { 2012) }\end{array}$ & $\begin{array}{l}\text { Maximize } \\
\text { positive aspects } \\
\text { and minimize } \\
\text { risks associated } \\
\text { with club sports. }\end{array}$ & $\begin{array}{l}\text { Literature } \\
\text { review. }\end{array}$ & N/A & N/A & $\begin{array}{l}\text { Several } \\
\text { recommendations; } \\
\text { schools should support } \\
\text { leadership goals } \\
\text { through training } \\
\text { leaders and providing } \\
\text { education throughout } \\
\text { the school year. Club } \\
\text { sports also provide } \\
\text { many positive } \\
\text { outcomes but also } \\
\text { have many inherent } \\
\text { risks that need to be } \\
\text { managed. }\end{array}$ \\
\hline
\end{tabular}




\begin{tabular}{|c|c|c|c|c|c|}
\hline Title/Authors & Purpose & Participants & Instruments & Procedures & Results \\
\hline $\begin{array}{l}\text { Differences in } \\
\text { leadership } \\
\text { development of } \\
\text { club sport } \\
\text { officers } \\
\\
\text { (Hall-Yannessa } \\
\text { \& Forrester, } \\
\text { 2004) }\end{array}$ & $\begin{array}{l}\text { Measure skill } \\
\text { development of } \\
\text { club sport } \\
\text { officers, } \\
\text { examines } \\
\text { differences in } \\
\text { reported } \\
\text { leadership skills } \\
\text { before, } \\
\text { immediately } \\
\text { following a one- } \\
\text { year leadership } \\
\text { role and } \\
\text { compares them } \\
\text { across positions. }\end{array}$ & $\begin{array}{l}222 \text { students at } \\
\text { the same } \\
\text { university }\end{array}$ & $\begin{array}{l}\text { Student } \\
\text { Leadership } \\
\text { Skills Inventory } \\
\text { (SLSI) }\end{array}$ & $\begin{array}{l}\text { Self-report, pre- } \\
\text { test, post-test, } \\
\text { repeated foe } 2 \\
\text { years, different } \\
\text { sample for pre- } \\
\text { test and post test }\end{array}$ & $\begin{array}{l}\text { The five leadership } \\
\text { skills gained were not } \\
\text { from those presented } \\
\text { in training, may need } \\
\text { to quantify the } \\
\text { learning outcomes of } \\
\text { intentional training } \\
\text { sessions, they } \\
\text { underrated themselves } \\
\text { in the pre-test because } \\
\text { they may not have had } \\
\text { such a leadership role } \\
\text { in the past. The five } \\
\text { skills learned: } \\
\text { sensitivity towards } \\
\text { diversity, self- } \\
\text { confidence in their } \\
\text { abilities, relating well } \\
\text { to the opposite sex in } \\
\text { a work-type situation, } \\
\text { respecting the rights } \\
\text { of others and } \\
\text { understanding the } \\
\text { consequences of their } \\
\text { actions. }\end{array}$ \\
\hline
\end{tabular}




\begin{tabular}{|c|c|c|c|c|c|}
\hline Title/Authors & Purpose & Participants & Instruments & Procedures & Results \\
\hline $\begin{array}{l}\text { A constructivist } \\
\text { case study } \\
\text { examining the } \\
\text { leadership } \\
\text { development of } \\
\text { undergraduate } \\
\text { students in } \\
\text { campus rec } \\
\text { sports } \\
\\
\text { (Hall, Forrester } \\
\& \text { Borsz, 2008) }\end{array}$ & $\begin{array}{l}\text { How leaders } \\
\text { benefited, the } \\
\text { leadership skills } \\
\text { they developed } \\
\text { as an outcome of } \\
\text { their leadership } \\
\text { experience. }\end{array}$ & $\begin{array}{l}13 \text { female, } 8 \\
\text { male, } 12 \text { in } \\
\text { sport clubs, } 4 \\
\text { special event } \\
\text { council, } 2 \text { rec } \\
\text { sports council, } \\
2 \text { intramural, } 1 \\
\text { fitness. }\end{array}$ & $\begin{array}{l}\text { Constructivist: } \\
\text { the interaction } \\
\text { between } \\
\text { researcher and } \\
\text { participant so } \\
\text { that the findings } \\
\text { are created } \\
\text { throughout. }\end{array}$ & $\begin{array}{l}\text { Interviews } \\
\text { combined with } \\
\text { documentary } \\
\text { evidence, } \\
\text { examine the case } \\
\text { from another } \\
\text { person's } \\
\text { perspective }\end{array}$ & $\begin{array}{l}\text { Seven broad themes } \\
\text { emerged: organizing, } \\
\text { planning, delegating, } \\
\text { balancing academic, } \\
\text { personal and } \\
\text { professional roles, } \\
\text { motivating/influencing } \\
\text { others, being a } \\
\text { mentor/role model, } \\
\text { communication skills, } \\
\text { problem solving and } \\
\text { decision making, } \\
\text { diversity, } \\
\text { giving/receiving } \\
\text { feedback. }\end{array}$ \\
\hline
\end{tabular}




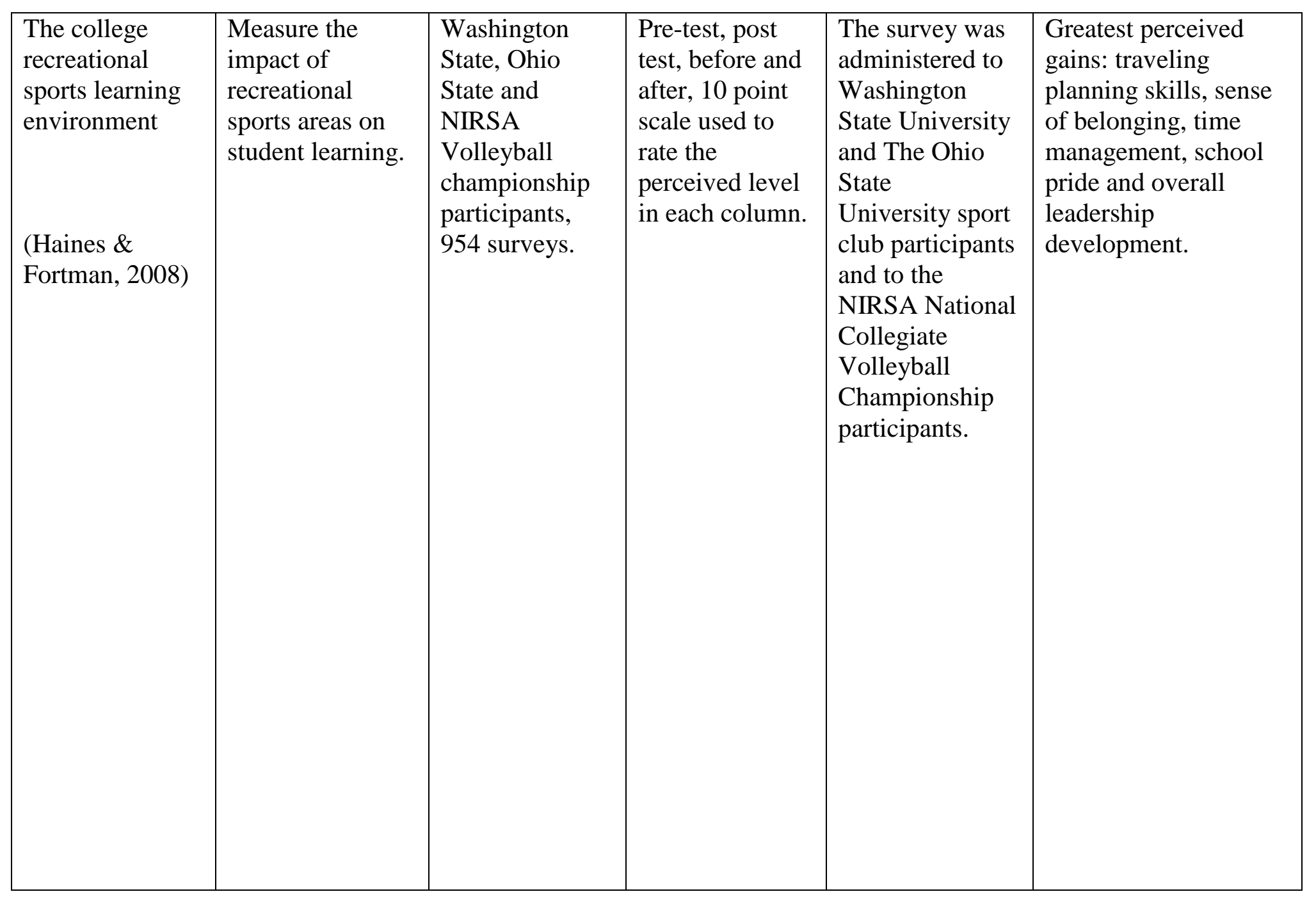




\begin{tabular}{|c|c|c|c|c|c|}
\hline Title/Authors & Purpose & Participants & Instruments & Procedures & Results \\
\hline $\begin{array}{l}\text { The "Ultimate" } \\
\text { experience: } \\
\text { Participation in } \\
\text { club sports a } \\
\text { source of } \\
\text { women's } \\
\text { development in } \\
\text { college } \\
\text { (Weis, 2007) }\end{array}$ & $\begin{array}{l}\text { To understand } \\
\text { the effects of } \\
\text { participation for } \\
\text { a small, unique, } \\
\text { well-defined } \\
\text { population of } \\
\text { female student } \\
\text { athletes on the } \\
\text { club Ultimate } \\
\text { Frisbee team. To } \\
\text { describe weather } \\
\text { and how } \\
\text { participation in } \\
\text { club sports helps } \\
\text { foster } \\
\text { development for } \\
\text { female college } \\
\text { students. }\end{array}$ & $\begin{array}{l}\text { Six women, } \\
\text { sophomores, } \\
\text { juniors and } \\
\text { seniors, who } \\
\text { were committed } \\
\text { members of the } \\
\text { women's } \\
\text { Ultimate } \\
\text { Frisbee team. }\end{array}$ & $\begin{array}{l}\text { Short, paper- } \\
\text { based } \\
\text { questionnaire } \\
\text { and structured } \\
\text { interviews. }\end{array}$ & $\begin{array}{l}\text { Participants } \\
\text { completed the } \\
\text { questionnaire } \\
\text { and were } \\
\text { interviewed. }\end{array}$ & $\begin{array}{l}\text { The participants do } \\
\text { acquire specific skills } \\
\text { from their } \\
\text { membership, their } \\
\text { college experience } \\
\text { improved by being a } \\
\text { part of an inclusive } \\
\text { community and by } \\
\text { learning the specific } \\
\text { skills through the } \\
\text { sport itself. Being a } \\
\text { member of this group } \\
\text { helped this group of } \\
\text { women enjoy and } \\
\text { thrive in college. }\end{array}$ \\
\hline
\end{tabular}




\begin{tabular}{|c|c|c|c|c|c|}
\hline Title/Authors & Purpose & Participants & Instruments & Procedures & Results \\
\hline $\begin{array}{l}\text { Impact of } \\
\text { advisor } \\
\text { interaction on } \\
\text { the development } \\
\text { of leadership } \\
\text { skills in sport } \\
\text { club officers } \\
\text { (Hall-Yanessa, } \\
\text { S., Forrester, S., } \\
\text { 2005) }\end{array}$ & $\begin{array}{l}\text { Examined } \\
\text { differences in } \\
\text { self-reported } \\
\text { leadership skills } \\
\text { developed by } \\
\text { students in sport } \\
\text { club leadership } \\
\text { positions and } \\
\text { compare } \\
\text { differences based } \\
\text { on the amount of } \\
\text { time per month } \\
\text { that officers } \\
\text { spend consulting } \\
\text { with their } \\
\text { advisor. }\end{array}$ & $\begin{array}{l}94 \text { students } \\
\text { participated (58 } \\
\text { males, } 32 \\
\text { females) the } \\
\text { average student } \\
\text { in this } \\
\text { population held } \\
3.47 \text { leadership } \\
\text { roles while } \\
\text { attending } \\
\text { college. }\end{array}$ & $\begin{array}{l}\text { Student } \\
\text { Leadership } \\
\text { Skills Inventory } \\
\text { that measures } \\
\text { leadership in } \\
\text { the following } \\
\text { five areas: } \\
\text { communication } \\
\text { skills, technical } \\
\text { skills, goal } \\
\text { setting and } \\
\text { attainment } \\
\text { skills, group } \\
\text { management } \\
\text { skills and } \\
\text { personal skills. }\end{array}$ & $\begin{array}{l}\text { Completion of } \\
\text { he SLIS and a } \\
\text { total number of } \\
\text { hours spent with } \\
\text { an advisor. }\end{array}$ & $\begin{array}{l}\text { Those students who } \\
\text { interacted with their } \\
\text { advisor more } \\
\text { frequently reported } \\
\text { higher leadership } \\
\text { skills development. }\end{array}$ \\
\hline
\end{tabular}




\begin{tabular}{|c|c|c|c|c|c|}
\hline Title/Authors & Purpose & Participants & Instruments & Procedures & Results \\
\hline $\begin{array}{l}\text { A survey of } \\
\text { sport club } \\
\text { programs }\end{array}$ & $\begin{array}{l}\text { The primary } \\
\text { purpose is to } \\
\text { enrich the } \\
\text { knowledge base } \\
\text { on sport club } \\
\text { programs. The } \\
\text { secondary } \\
\text { purpose was to } \\
\text { gain a better } \\
\text { understanding of } \\
\text { how these } \\
\text { programs operate } \\
\text { in terms of their } \\
\text { organizational } \\
\text { structure and } \\
\text { finances. }\end{array}$ & $\begin{array}{l}\text { Sport Club } \\
\text { programs from } \\
\text { twenty-six } \\
\text { universities } \\
\text { were sent a } \\
\text { self-developed } \\
\text { questionnaire of } \\
\text { thirteen items. } \\
\text { Twelve } \\
\text { programs } \\
\text { responded to } \\
\text { the } \\
\text { questionnaire. }\end{array}$ & $\begin{array}{l}\text { A self- } \\
\text { developed } \\
\text { questionnaire of } \\
\text { thirteen items. }\end{array}$ & $\begin{array}{l}\text { Leaders from the } \\
\text { twelve } \\
\text { universities } \\
\text { completed the } \\
\text { questionnaire. }\end{array}$ & $\begin{array}{l}\text { The study showed that } \\
\text { sport club programs } \\
\text { involved a significant } \\
\text { number of students, } \\
\text { ranging from 120- } \\
4,100 \text { members. Also, } \\
\text { the researcher } \\
\text { suggested the NIRSA } \\
\text { can help guide clubs } \\
\text { by establishing } \\
\text { common terms to } \\
\text { describe the sport club } \\
\text { program because } \\
\text { many programs used } \\
\text { different terminology } \\
\text { which was hard to } \\
\text { compare across } \\
\text { different schools. }\end{array}$ \\
\hline
\end{tabular}




\begin{tabular}{|c|c|c|c|c|c|}
\hline Title/Authors & Purpose & Participants & Instruments & Procedures & Results \\
\hline $\begin{array}{l}\text { Rise of college } \\
\text { club teams } \\
\text { creates a whole } \\
\text { new level of } \\
\text { success } \\
\text { (Pennington, } \\
\text { 2008) }\end{array}$ & $\begin{array}{l}\text { To raise } \\
\text { awareness of the } \\
\text { rise in popularity } \\
\text { of club sport } \\
\text { programs. At the } \\
\text { time of this } \\
\text { report, an } \\
\text { estimated two } \\
\text { million college } \\
\text { students played } \\
\text { competitive } \\
\text { sports as opposed } \\
\text { to the } 430,000 \\
\text { students that play } \\
\text { in association } \\
\text { with the National } \\
\text { Collegiate } \\
\text { Athletic } \\
\text { Association. }\end{array}$ & N/A & N/A & N/A & $\begin{array}{l}\text { The outsize of youth } \\
\text { sports culture can also } \\
\text { be attributed to the } \\
\text { rising number of high } \\
\text { school athletes who } \\
\text { are looking to } \\
\text { continue their } \\
\text { involvement in } \\
\text { college. Club sports } \\
\text { are an avenue for } \\
\text { athletes to participate. } \\
\text { The participants of the } \\
\text { teams shape and } \\
\text { influence the } \\
\text { philosophy of their } \\
\text { team and being active } \\
\text { in the leadership of a } \\
\text { club sport teaches a } \\
\text { wealth of knowledge } \\
\text { that college students } \\
\text { might not learn } \\
\text { anywhere else. }\end{array}$ \\
\hline
\end{tabular}




\begin{tabular}{|c|c|c|c|c|c|}
\hline Title/Authors & Purpose & Participants & Instruments & Procedures & Results \\
\hline $\begin{array}{l}\text { Sports and } \\
\text { community on } \\
\text { campus: } \\
\text { Constructing a } \\
\text { sports } \\
\text { experience that } \\
\text { matters } \\
\text { (Dixon \& } \\
\text { Warner, 2013) }\end{array}$ & $\begin{array}{l}\text { To explore } \\
\text { factors which } \\
\text { build a strong } \\
\text { sense of } \\
\text { community } \\
\text { among sport club } \\
\text { participants. }\end{array}$ & $\begin{array}{l}21 \text { (10 females, } \\
11 \text { males) } \\
\text { former college } \\
\text { sports club } \\
\text { athletes who } \\
\text { just recently } \\
\text { graduated (1-5 } \\
\text { years) who } \\
\text { played on a } \\
\text { competitive } \\
\text { sport club. }\end{array}$ & $\begin{array}{l}\text { Semi structured } \\
\text { interviews were } \\
\text { conducted. }\end{array}$ & $\begin{array}{l}\text { Participants } \\
\text { were contacted } \\
\text { through } \\
\text { directors of } \\
\text { sports club } \\
\text { programs and } \\
\text { asked for their } \\
\text { availability for a } \\
\text { phone interview. }\end{array}$ & $\begin{array}{l}\text { Four salient factors } \\
\text { emerged that } \\
\text { contribute to a sense } \\
\text { of community for } \\
\text { sports clubs. They are: } \\
\text { common interest, } \\
\text { leadership } \\
\text { opportunities, } \\
\text { voluntary activity and } \\
\text { competition. If } \\
\text { administrators are } \\
\text { made aware of these } \\
\text { factors, they can } \\
\text { encourage participants } \\
\text { in structuring their } \\
\text { programs in such a } \\
\text { manner where all four } \\
\text { of these areas are } \\
\text { taken into } \\
\text { consideration. }\end{array}$ \\
\hline
\end{tabular}




\section{Chapter 3: Methodology}

\section{Overview of the Methodology}

This study utilized a qualitative approach. Qualitative research seeks to "understand how people interpret their experiences, how they construct their worlds, and what meaning they attribute to their experiences" (Merriam, 2009, p. 5). This approach seeks to comprehend a human being's description of a particular situation. The goal of qualitative research, such as the present study, is to uncover and understand a phenomenon from the perspective of the individual living the experience (Creswell, 1998).

\section{Epistemology}

There are different paradigms to view a case study such as positivism, transformational, and constructivism. The positivist approach works deductively to explore "causal relationships on the basis of generalized knowledge" (Paré, 2001). This is a quantitative approach where the researcher is removed from the process; he or she cannot engage in judgments of the data or provide his or her subjective opinion (Paré). Contrary to this paradigm, the present study employed the constructivist approach.

The constructivist approach is that "truth is relative and that is dependent on one's perspective" (Baxter \& Jack, 2008, p. 545). In the constructivist approach, knowledge is built through a construction of reality between the researcher and participants (Searle, 1995). The researcher is the instrument for data collection. Through this claim, the researcher and participant collaborate to create the data, which enables participants to fully tell their stories (Crabtree \& Miller, 1999). 


\section{Case Study}

One form of qualitative research is the case study. A case study is "an in-depth description and analysis of a bounded system" (Merriam, 2009, p. 41). The bounded system, according to Creswell (1998), is bounded by time and place. Case studies are interpretive; they are attuned to the fact that research is a researcher-subject interaction. The case study assumes that there are no simple answers and does not intend to simplify what cannot be simplified (Merriam).

According to Stake (1995), the researcher serves as a point of interpretation because of the researcher's involvement in the study and given the constructivist paradigm, the researcher offers a personal view. Qualitative research, such as a case study, requires continuous attention that is different than the attention needed when instruments of data collection are objectively interpretable checklists or survey items (Stake). The nature of the case study allows for interpretation and construction of the data, which requires a method such as an interview, which is more open to interpretation.

The specific qualitative design utilized in this study was an intrinsic case study. The intrinsic case study was employed because of the researcher's interest in the topic (Creswell, 1998). In an intrinsic case study, there is little interest in generalizing to the species or general population; the researcher is not interested in others. The researcher's interest lies in the particular case, to examine a part or a whole, seeking to understand what the specimen is and how the specimen works (Stake, 1995). For example, this study's interest was solely in sport club presidents; the researcher was not interested in other sport club members that may be referenced by the participants. 
Case studies have limitations and criticisms, similar to most research methods. The case study approach receives disapproval because the conclusions are said to be "highly subjective" and the data is often "unique to the studied event or process" (George \& Bennett, 2004, p. 19). Additionally, because of the focus on the "case" of study and the specific specimen, this type of research design "provides little basis for scientific generalization" (Yin, 2009, p. 15). However, the goal of the present study was to understand the participant's perspectives and the context in which the experiences occur. Since the researcher was interested in the experiences of sport club presidents, a case study was an ideal approach. The "case" under investigation was a group of students who held the position as "president" of their sport club. This research fit the intrinsic case study approach because the researcher was interested in the participant's experiences. The researcher did not intend to generalize these results to other participants; the intention was to gather rich, holistic data from participants to better understand their experience.

\section{Research Site}

The research site for this study was a campus recreation department located within a mid-sized institution of higher education in the Mid-Atlantic region of the United States. The department was comprised of recreation programs including: fitness, adventure, group fitness and wellness, aquatics and safety, sport clubs, summer camps, and intramural sports. The main recreational facility was a three-story building that included an atrium, an indoor track, a main gym, a multi-activity center, a 25 -yard by 25 meter swimming pool, an equipment center as well as a two-level (9,000 sq. ft.) fitness center with strength and cardio equipment. 
The staff at the recreation center consisted of 30 full-time professionals, nine graduate assistants and 409 student employees. Seven of those employees were dedicated to the sport club program. The employees dedicated to the sport club program were the Assistant Director, Coordinator, Graduate Assistant, and four student staff members who served as the "Sport Club Council." All members of the Sport Club Council, the Graduate Assistant, and the two professional, full-time employees indirectly supervised the sport club presidents, as shown in Figure 1. The presidents served as the point of contact for their club. Two of the members of the Sport Club Council also served as presidents of their clubs. They did not participate in the study because of the supervisory relationship that existed with the researcher who was the Graduate Assistant. 


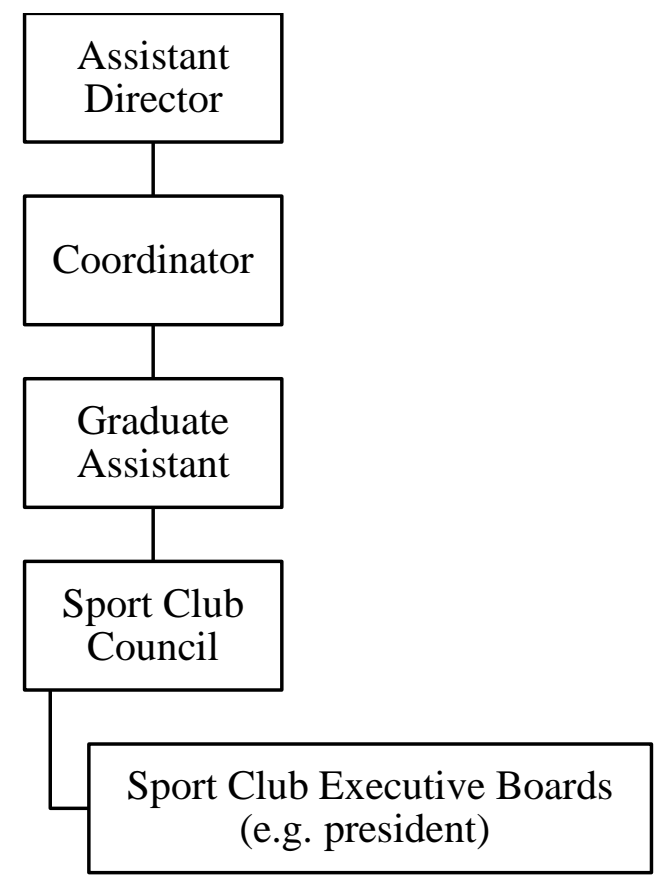

Figure 1. Sport Club Organizational Chart

The request for access was discussed with the Senior Associate Director and the Director of the department as well as the Assistant Director who directly supervised the presidents of each club. A letter for approval (Appendix A) was sent to the Director, which asked for written permission for access to the participants. The Director responded with approval to use the subjects.

\section{Study Participants}

Sampling is important because of the emphasis on the case and bounded system in case studies (Stake, 1995). Purposive sampling was employed in this study. Criterion sampling, or selecting participants based on pre-determined criteria, was utilized (Merriam, 2009). The researcher sampled the most involved member of each sport club. The presidents of the sport clubs were recruited for this study because this student had the highest leadership role attainable on a sport club. The duties and responsibilities, inferred 
by the policies and role description in the Sport Club Manual, suggested that the presidents' commitment to their club might have been greater than other members.

The bounded system in this study was the sport club program at the university. This group fit the bounded system because the program was clearly identifiable and limited in scope. The participants were presidents of sport clubs within the university recreation center at the institution during the 2013-2014 school year. The sport club leadership board, which consists of an Assistant Director, Coordinator, Graduate Assistant and four undergraduate student employees, hosted a training session for all executive members (e.g., president, vice-president, secretary, treasurer) in August. Before the training, all the presidents received an information email (Appendix B) which described the purpose of the study, confidentiality, and requirements of their voluntary participation. The presidents were invited to participate in the study during the training. Students were given information about the study (Appendix C) including the purpose of the study, description of the time and involvement necessary to participate in the research, and potential interview times during the month of December.

Students who chose to participate in the study signed a consent form (Appendix D). In order to maintain confidentiality, the researcher did not disclose the names of the participants throughout the study, but rather used pseudonyms on all documentation. Information collected from the journals and interviews were kept in a locked cabinet drawer at the researcher's desk in the University Recreation Center.

Students met with the researcher at the University Recreation Center to clarify their requirements and were assigned a pseudonym. The students were instructed to use 
this name in their journal entries. The researcher labeled all interviews using the respective pseudonym.

Eleven sport club presidents, five female and six male, served as the case for this study. Table 4 provides the demographic information of the study participants. At the time of data collection, each president served in the program from six to twenty-nine months. The average amount of months serving in the role was 16 months. Participants were 18-22 years old. Eight of the participants were seniors and three participants were juniors. The participants studied a variety of majors including Health Studies, Economics, Math, Secondary Education, and Dietetics. 
Table 4. Study Participant Demographics

\begin{tabular}{|c|c|c|c|c|c|}
\hline Pseudonym & $\begin{array}{l}\text { Academic } \\
\text { year }\end{array}$ & $\begin{array}{l}\text { Academic } \\
\text { major }\end{array}$ & $\begin{array}{l}\text { President } \\
\text { (months) }\end{array}$ & $\begin{array}{l}\text { Membership } \\
\text { (months) }\end{array}$ & $\begin{array}{l}\text { Other } \\
\text { clubs/organizations }\end{array}$ \\
\hline Ann & Junior & $\begin{array}{l}\text { Health } \\
\text { Services } \\
\text { Administration } \\
\text { General } \\
\text { Business minor }\end{array}$ & 6 & 29 & $\begin{array}{l}\text { Health } \\
\text { Administration } \\
\text { Students } \\
\text { Association and } \\
\text { student employee }\end{array}$ \\
\hline Charlie & Senior & $\begin{array}{l}\text { Finance and } \\
\text { Economics }\end{array}$ & 6 & 41 & $\begin{array}{l}\text { Catholic Campus } \\
\text { Ministries and } \\
\text { Swing Dance }\end{array}$ \\
\hline Chet & Senior & $\begin{array}{l}\text { Health Studies } \\
\text { and } \\
\text { Kinesiology }\end{array}$ & 15 & 29 & $\begin{array}{l}\text { Delta Upsilon } \\
\text { Fraternity }\end{array}$ \\
\hline Elizabeth & Senior & $\begin{array}{l}\text { Math and } \\
\text { Secondary } \\
\text { Education }\end{array}$ & 15 & 41 & $\begin{array}{l}\text { Phi Mu Epsilon } \\
\text { and the } \\
\text { Association of } \\
\text { Women in } \\
\text { Mathematics }\end{array}$ \\
\hline Gabby & Senior & $\begin{array}{l}\text { Intelligence } \\
\text { Analysis and } \\
\text { Middle Eastern } \\
\text { Communities } \\
\text { and Migrations } \\
\text { minors }\end{array}$ & 6 & 29 & $\begin{array}{l}\text { Member of Alpha } \\
\text { Phi Omega }\end{array}$ \\
\hline Galen & Senior & $\begin{array}{l}\text { Economics and } \\
\text { a minor in } \\
\text { Integrated } \\
\text { Environmental } \\
\text { Science and } \\
\text { Technology }\end{array}$ & 6 & 41 & N/A \\
\hline Gary & Junior & Dietetics & 6 & 29 & $\begin{array}{l}\text { Dietetics } \\
\text { Association }\end{array}$ \\
\hline Madeline & Senior & $\begin{array}{l}\text { Kinesiology, } \\
\text { concentration } \\
\text { in Exercise } \\
\text { Science, minor } \\
\text { in Coaching }\end{array}$ & 6 & 41 & N/A \\
\hline Marie & Junior & $\begin{array}{l}\text { Geographic } \\
\text { Science and } \\
\text { minor in } \\
\text { Environmental }\end{array}$ & 17 & 29 & Geography Club \\
\hline
\end{tabular}




\begin{tabular}{|l|l|l|l|l|l|}
\hline & & Studies & & & \\
\hline William & Senior & $\begin{array}{l}\text { Finance and } \\
\text { minor in } \\
\text { Economics }\end{array}$ & 6 & 29 & $\begin{array}{l}\text { Madison } \\
\text { Investment Fund } \\
\text { and a student } \\
\text { employee }\end{array}$ \\
\hline Zack & Senior & Kinesiology & 29 & 41 & N/A \\
\hline
\end{tabular}

\section{Data Collection}

\section{Interviews}

Through semi-structured world life interviews, the meaning participants attributed to their experience as a sport club president was discovered. Kvale and Brinkmann (2009) define the semi-structured interview as "an interview with the purpose of obtaining descriptions of the life world of the interviewee in order to interpret the meaning of the described phenomena" (p. 27). This type of interview gives the interviewee predefined questions, but allows freedom and flexibility in the flow of the conversation. A semistructured life interview, "is neither an open every day conversation, nor a closed questionnaire" (Kvale \& Brinkmann, p. 27). An interview is a conversation that has structure and purpose. Specifically, the researcher conducted research interviews, which are "based on the conversations of daily life" (Kvale \& Brinkmann, p. 2). Semi-structured interviews allowed the researcher to learn about the participants, their experiences, feelings, and attitudes about the world in which they live (Kvale \& Brinkmann).

Each participant has a unique perspective of his or her time in the sport club program and their respective club. The interviews allowed the researcher to gain access to the rich and detailed descriptions from the participants. This type of data collection was fitting for the study because of the constructivist nature that qualitative interviews 
possess. Although the interviews persistently followed a specific line of inquiry, the stream of questions in a case study interview is likely to be "fluid rather than rigid" (Yin, 2009, p. 106). Participants were informed that the purpose of the study was to understand their experiences as the president of their sport club and therefore, were encouraged to answer as openly and honestly as possible.

Interviews were conducted at the University Recreation Center at the convenience of the interviewee and the researcher. Interviews lasted approximately 30 minutes, depending on the length of responses. The researcher recorded all interviews using a digital recording device and took notes for assistance. A transcript of each interview was saved on the researcher's computer at the University Recreation Center.

The participants were instructed to share their experiences but were not limited in the depth and scope of information they provided. The researcher prompted participants to share reasons for beginning involved in the leadership position, using questions from the interview guide (Appendix F) such as "what is the most significant experience you have had as president?" Other questions elicited reflection on their leadership role, such as "have your experiences as a president of your particular sport club influenced or not influenced you in the decisions you have made in your life? How so?”

\section{Journals}

A second method of data collection was reflective journaling. Reflective journals are described as a "handwritten or verbal account of an event, or a group of events, over time" (Stake, 1995, p. 36). Journaling allowed the participants to share their subjective account of an event or experience. Diaries and personal journals offer an interesting way 
for researchers to "explore the ways that participants construct meaning around [their] intimate lives" (Harvey, 2011, p. 678).

Students wrote and submitted weekly journals, approximately one-paragraph in length, throughout eight weeks of their experience. An email addresses was created for the submission of journals and deleted upon submission of the last journal. Individuals were asked to reflect on the current week and write about anything pertinent to their role as president. The researcher instructed participants to provide support for their ideas to improve the quality of submissions. Participants emailed their journals to the researcher each Sunday of the eight-week session, beginning September 8, 2014, through October 27, 2014. Each journal was saved on the researcher's computer, which was locked, at the University Recreation Center.

\section{Document Analysis}

The third method of data collection was document analysis. Document analysis is described as "a systematic procedure for reviewing and evaluating documents, printed and electronic" (Bowen, 2009, p. 28). Document analysis requires that data be examined and interpreted in order to elicit meaning, gain understanding and develop empirical knowledge (Bowen). Documents, in this case, was a broad term used to define texts, sounds, photos, videos and any materials that carry relevant messages. The researcher examined the program's "Sport Club Manual” and Sport Club Officer Training outlines.

\section{Data Analysis}

Qualitative analysis allows for a discovery of a "story line" and the opportunity to analyze the case from the perspectives of individuals living the experience as well as the 
researcher's involvement (Creswell, 1998). During the data analysis phase, the researcher begins to make sense out of the data that is collected. Merriam (2009) explained that data analysis involves an investigation of the research question and units of data that are meaningful.

\section{Content Analysis}

The mode of analysis for this case study was pattern recognition, or content analysis. This is the ability to see patterns throughout information and insights in which "situations, settings, styles, images, meanings and nuances are key topics" (Merriam, 2009, p. 205). Content analysis allowed the researcher to investigate trends in the data that were meaningful. Interviews and journals were directly examined. The first step involved the inductive identification of salient codes that described and represented the participant's experiences and the researcher's interpretation of those experiences. For example, as participants described their involvement, "putting the whole team before myself," "being a leader," and "learning experience," was constructed from the data and was coded accordingly. This open coding approach allowed the data to be analyzed inductively, where the discovery of patterns, themes and categories was conducted. Through this approach, the researcher, serving as an instrument in the analysis of the data, constructed the findings. The researcher categorized, or coded, the data and in result, constructed themes of related information. In addition, the data received through interviews and journals were coded by information that connected and related. A summary of themes was constructed from this categorization.

The themes were compared to the findings from the literature on student development and involvement. A constant comparative method of analysis was used to 
discover conceptual links between and among the data (Merriam, 2009). The constant comparative method allows the researcher to simultaneously code and analyze the data “in order to develop concepts" (Taylor \& Bogdan, 1984, p. 126). This happens by continuously comparing specific incidences in the data throughout the entire data set in order to find relationships between and among the data (Taylor \& Bogdan, 1984). In order to organize the data collected and manage the information well, a case record was created. A case record is the data of the study, which organizes the information so that the researcher can more readily access information (Merriam).

\section{Trustworthiness}

\section{Triangulation}

Triangulation is the use of multiple sources of information, which serves as the "convergence of sources of information, views of investigators, different theories and different methodologies" (Creswell, 1998, p. 251). Triangulation is the belief that multiple viewpoints allow for greater accuracy. In order to ensure verification and trustworthiness of the study, triangulation was conducted through the use of three data collection methods. This case study utilized this combination of methodologies to deeply study the individuals and cross reference for validity (Jick, 1979). This study's three points of triangulation were interviews, journaling and document analysis.

\section{Member Checking}

Stake (1995) recommends conducting "member checking" which allows "the person who provided the information [the opportunity] to determine if the researcher has accurately reported their stories" (Koelsch, 2013, p. 170) Member checking is a strategy to reveal research materials to the participants in order to ensure that the researcher 
accurately translated the viewpoints into data (Krefting, 1991). This decreases the chance of misrepresentation and increases the rigor of the data as well as the validity (Koelsch). Member checking is a means of assessing validity in a study because "the first step of many qualitative projects is to accurately understand the participant's worldview" (Koelsch, p. 170). Participants were emailed a transcript of the interview and their journals to check for accuracy as well as a summary of the themes that were constructed. Although participants were given the opportunity to make corrections to the data presented to them, the researcher could chose to accept or decline any corrections or recommendations from the participants.

\section{Researcher Positionality}

This study employed an epistemological philosophical assumption because of the researcher's role within the club sport program. At the time of this research, the researcher was the Graduate Assistant for the sport club program. She had three and a half years of experience working with the presidents of sport clubs within the program and was a sport club president herself as an undergraduate. In her job duties, she, along with her supervisor, served as a mentor to each of the presidents of the clubs. This subordinate relationship may have influenced the participant's interviews and journal responses. Her role in the program may also have affected the way the data was interpreted. She created leadership opportunities and workshops for presidents. She may have viewed the data as more positive or relating to more learning outcomes that existed. The researcher may also use her own experiences as a president to construe the responses and reflections from the participants. 
According to Creswell (1998), in epistemological research, a prolonged amount of time spent in the field closes the gap between the researcher and that of the participants and setting. This is a strong method because of its ability to answer complex social units and the rich, holistic information that results (Merriam, 2009). The researcher then becomes an insider of the phenomenon being studied. This approach can compromise the values and integrity of the study if they are not addressed and considered. The researcher addressed any bias in order to minimize any weakness in this particular study.

\section{Human Participants and Ethics Precautions}

The James Madison University Institutional Review Board approved the procedures for the study participant recruitment and research design. Data was not collected until approval was attained.

The study participants for this research were sport club presidents. The researcher had a relationship with the participants because she was the Graduate Assistant for the sport club program. An email was sent to all sport club presidents informing them on the study and their voluntary participation. Participants were recruited during a training held for all sport club officers. Presidents were informed that all information, including their names and sport club, would be kept confidential. A recruitment briefing (Appendix C) was provided to all potential participants. At the training, those who expressed interest in the study completed the consent form (Appendix D). Those who completed the consent form were contacted by email to meet the researcher, one-on-one, at the university recreation center to explain the details and requirements of their participation. During the meeting, participants created their pseudonym, they were given journal instructions (Appendix E), and the researcher and participants scheduled an interview time for the end 
of the semester. All requirements were reviewed in detail and the participants were encouraged to ask any questions for clarification. Several presidents who signed the consent form did not complete a one-on-one meeting and therefore, opted out of participation.

\section{Overview of the Chapter}

The research was conducted using a qualitative research tradition. An intrinsic case study was the performed to describe the president's experiences. The case consisted of 11 sport club presidents. Data were collected utilizing three methods: journals, interviews and document analysis. The presidents submitted weekly journals electronically for an eight-week period and the interviews were conducted over one week. Content analysis was utilized to make meaning from the data. Codes were constructed from the data and patterns and themes emerged through a constant comparative method to find commonalities between and among the interview transcripts, journals and documents. Triangulation, member checking and awareness of the researcher's position were considered for the trustworthiness of this study. 


\section{Chapter 4: Results}

\section{Findings by Data Collection Methods}

Four themes were constructed from the data. They were social competence, vocational competence, practical competence, and involvement. Kuh (1995) developed a taxonomy of outcomes in his study on student learning and personal development. His study supports the construction of vocational competence, social competence, and practical competence. The other 11 outcomes described in Kuh's taxonomy were beyond the scope of this data. Additionally, Keeling (2006) identified student-learning outcomes. One of the seven outcomes in this report, interpersonal competence, was described as the "ability to work with people different from self" (p. 24). This construction relates to social competence, which was a theme constructed from this study's data.

The final theme constructed from this data was involvement. Astin's Theory of Involvement, in the student development and involvement literature, supports this construction. Involvement is defined as the amount of "physical and psychological energy the student commits to the campus environment" (Astin, 1984, p. 297). The theme of involvement was similarly separated into the subthemes: physical time and psychological time.

\section{Social Competence}

According to Kuh (1995), social competence is defined as “intimacy, working with others, leadership, dealing with others, assertiveness, flexibility and public speaking" (p. 150). Presidents described how their involvement improved their abilities with public speaking, working with others, assertiveness, and leadership. 
Public speaking. Specifically, students described improvements in their selfconfidence because of the public speaking that was required within the role. The president position required study participants to speak out and push themselves outside of their comfort zone. Chet described, in his interview, his development of self-confidence by saying, "I was never very vocal with other people, I was always very shy and just seeing in the few semesters where this has taken me. I'm like a new person, I can talk in front of groups, it was always a pretty tough thing for me." Similarly, in his interview, Gary shared a transferable progression of confidence to the classroom. Gary said, "in class I don't normally raise my hand, like answer questions, but I've been doing that more lately talking during class and stuff because I am used to speaking out loud in the president role. I'd say it's helped my confidence." The way that the presidents explained how speaking in public to their teammates transferred to different settings suggests that the students gained confidence in themselves and their abilities, as well as a more positive perspective on public speaking.

Working with others. The role required students to hold others accountable to accomplish tasks and goals. In result, study participants learned to hold others responsible for their actions and commitments. In her interview, Elizabeth shared a transferable experience from her personal life to her role as president, where she learned to hold her roommates accountable. As the president she was often the person who would have difficult conversations with members who did not attend events and difficult conversations requiring members to participate in team events. She said that her experience as the president changed her as a person. As an underclassman, before she served in the role as president, she described herself as the "biggest pushover ever" in her 
relationships with her roommates. She would be the one taking out the trash, doing the dishes and she would seldom voice her concerns to her roommates. However, after serving in the role and gaining social competence, she gained courage.

[Being president] kind of made me stand up. It helped like that. I did it more in swimming where I was leading things and telling people like, directing them towards things, whereas with my roommates I would be doing it and I was able to tell them I don't want to do it anymore, I could stand up for myself.

Although many of the participants were friends with their teammates, they learned that they needed to be impartial, fair, and, at times, assertive to all members. In her journal, Ann shared that this experience “made me more direct because I can't beat around the bush and keep it open to interpretation...if something needs to be done I need to say straight up, this is what needs to be done, this is when I need to know by." Similarly, Gabby dealt with many interpersonal concerns with her teammates, such as some teammates not getting along with one another. Through this experience, Gabby learned not to take things personally. She realized that some teammates appreciated her work, and others may not have always agreed with her decisions or valued her as the president. She learned to accept this and maintain confidence in her abilities. She recognized this challenge saying, "it is a challenge to make such a large group of people happy."

Charlie noticed that he became "much more well-rounded and able to work with different types of personalities." Club members shared commonality in their sport, but not necessarily other harmonies. Therefore, presidents learned how to lead a variety of constituents. Elizabeth also described her experience utilizing the term "people 
management." She led a team of 120 members and she learned that she could not always please everyone.

Leadership. Students also described their role as an altruistic leader. They learned the value of placing others, or the team's, interests before their own. The presidents consistently reported having to do what was best for the team. According to Gabby, who was planning on teaching abroad upon graduation from college, the position, "teaches you how to deal with all different kinds of people." Similarly, Chet said that he grew as "someone who is not putting themselves in front of others but putting the team first." Gary described the leadership experience as difficult and that it was challenging to ensure that all members of the club were happy. Through this difficulty, he learned that as a leader, "you can't be self-centered, you have to think about what is better for everyone overall... [being president] is more of a selfless role."

Social competence was constructed through document analysis. The Sport Club Executive Training document cited "leadership based decision making" as a training topic and the term "leadership" three times throughout. The documents did not support the construction of confidence, assertiveness, or public speaking. This may have been because these skills were difficult to describe. Another reason could be that the program's professional staff was unaware that students described their experience in this way and therefore, this was not a topic addressed in training or a responsibility described in the manual.

\section{Vocational Competence}

Vocational competence, according to Kuh (1995), is defined as "acquiring attitudes, behaviors, and skills related to post college employment" (p. 151). Students 
described how their experience as president would be useful in their future and demonstrated advances in their leadership that could guide them in their life outside of college.

Leading in different settings. In their interviews, study participants described their satisfaction with their involvement as president and how they progressed throughout the role. This progression led to gains in confidence and the increase in confidence made them want leadership roles in the future. Marie described her experience by saying that she likes leadership roles. She also said, "I learned that I can step into leadership roles pretty well when it comes down to it so I think that I definitely want to...be able to take leadership roles there as well." Gabby said that being president "was the busiest leadership role or the one that comes with as much work as this did." This role demonstrated to her that "leadership roles are a lot to take on." Perhaps this experience will deter her from leading in different settings.

Transferable skills. The presidents described the skills they attained that will also be useful in different settings such as taking initiative, delegating, flexibility, and "real world" experience.

Involvement provided Charlie with an experience that he was able to reference in job interviews. In his journal, he mentioned that, as he was in the process of applying for jobs after graduation, he realized that many of the people he was interviewing with had "absolutely crazy working experience." He was initially discouraged by the amount of experience his peers were able to share during the interview process. He thought about the skills he learned from being president, and realized that they were very similar skills 
as the interviewees who had multiple work experience. Charlie mentioned his experience as the president in every interview.

Along with Charlie, many of the students described how this leadership experience would apply directly to future internships and jobs. Elizabeth, in her interview, related this position directly to her role as a teacher in the classroom. She said she learned the value of flexibility. This trait will be important because she said that "when doing a [teaching] lesson you always need to be flexible. Sometimes your class won't respond to your lesson the way you want to and you need to be able to change what you're doing so that they understand your lesson."

In his interview, William mentioned a skill he learned that he will use in his future job in the field of Finance saying, "if I was ever a manager or a team leader in a group or something I think that it is directly comparable to that, instead of taking on a project all to myself I would delegate parts to other people." Similarly, in his interview, Chet said, "eventually I want to go on to physical therapy and I need to be able to make decisions on different exercises I prescribe to my patients... so I need to be able to take the initiative and I think that is something I have seen myself grow in." Participants emphasized the practicality the position served related to their academic majors and degree aspirations. Marie illustrated this by comparing her involvement as president to her academic courses. She stated, "this is like an actual experience whereas the academics aren't real life always... this has been more practical than academics because it's like real world things I have had to deal with rather than scenarios and things I learn about in class." 
Additionally, the documents supported the construction of vocational competence. This theme was expected through the role because of the duties given to club presidents and the emphasis from the documents that the clubs were "student-run" and "selfgoverned." For example, presidents were responsible to "administer all club meetings."

\section{Practical Competence}

Kuh (1995) defined practical competence as "decision making, organizational skills, time management, budgeting and dealing with systems" (p. 150). The third theme constructed from the data demonstrates that participants gained management skills and experience managing people. Specifically, the management skills that they developed were time management, delegation, coordination and planning, and decision-making.

Time management. As a result from limited time, because of other commitments such as course work, and the physical involvement given to this position, the study participants described challenges managing their time. The students learned how to allot time during the day to make time for presidential duties. In his interview, Gary mentioned that this position "helped my work ethic. I like to be lazy but when I have stuff going on I can't be and so I've gotten better about making sure I get work done first and making sure I have free time for myself." Charlie learned the value of planning in relation to his time management. In his interview he said, "I will always plan out my weeks on Sunday, plan out the mornings and the nights. That is just something that is a really good skill I learned."

Delegation. Presidents learned the value of delegation and trusting members on their team and executive board to carry out assigned tasks. William, in his journal, described how he learned the "importance of delegation." According to William, "there is 
always so much to do for the team, and I want to do it all, but there is not nearly enough time to get everything done that I would like to, so I have been learning to trust others with getting things done for the team." Similarly, in his journal, Charlie spoke about the relationship between delegation and leadership. He proclaimed that leaders may not be the ones who do the most work, but they are the ones "who inspire others to accomplish great things." He initially learned this by trying to do too many of the tasks at the onset of this role instead of delegating work to other executive members.

Planning and coordinating. Students learned how to plan and coordinate events, competitions, practices, transportation, and fundraisers. Madeline learned, when planning her club's meetings that she has to write her goals and ideas down and map her message in advance. She said this is "something I learned and something I take away with me for other things now. I find it very beneficial to actually think about what I'm going to say before I say it." Presidents learned how to manage a budget and the value of effective preparation.

The study participants spent much of their role planning for events and coordinating during the event. For example, Elizabeth explained that before attending a competition she "had to print directions, make relays, organize vans [for travel], and cook." Once she and her team arrived to the competition, she "had to get everyone [ready], do scratches [for entries], help get everyone where they needed to be, give out caps, and go to a president meeting." In result of this planning and coordinating, study participants learned the value of punctuality and organization. Gabby said that the role "just makes you a more considerate personal all around." The presidents were also responsible for administrative duties such as managing paper work, such as attendance 
and forms required by the Sport Club Council. Through this responsibility, the study participants learned effective management techniques. Marie innovated her club's old system and created a google drive as opposed to "having paper trails everywhere."

Decision-making. The presidents gained competence in decision-making, or selecting a course of action among several possibilities. The presidents learned that they would not always be able to please everybody, it is difficult to be fair, and that leaders cannot let relationships get in the way of doing what is right. Ann and Elizabeth, in their journals and interviews, both described that they "hated being the mean guy," and Elizabeth, in her journal, recognized that "sometimes the decision you make isn't the most popular one but in the end it will be better for the team." When making decisions on the roster, Marie said, "it's hard to be in the position that you have to chose between your friends, hopefully they will understand the choices I made."

Presidents also described their time as a learning experience because sometimes they would make a judgment they later regretted; they learned from these experiences. Often times, the presidents served as a "sounding board" for conflicts that arose between members of their clubs. Chet described that, as the president, he needed to hear both sides and make decisions for the overall well-being of the team.

The Sport Club Manual supported this theme of practical competence by stating that "club officers are responsible for confirming all requests and for informing the Assistant Director of all upcoming activities, contests, meetings [and] events.” In addition, the club officers, including the presidents, were required to submit and plan practice requests as well as travel forms up to one month prior to the event. The document stated that presidents coordinate activities, schedule competitive events, and 
organize transportation. They are also required, along with their executive team, to “complete and submit all required forms, reports, and requests by the established deadlines and maintain financial records." The sub-theme of decision-making was also supported in the documents because a topic at the Sport Club Executive Training was "leadership based decision making" and in the Sport Club Manual presidents were given the responsibility to "discipline members for any problems that may arise."

\section{Involvement}

The final theme constructed from the data was involvement. Involvement was defined as the "amount of physical and psychological time the student commits to the campus" (Astin, 1984, p. 297). Students demonstrated involvement in their president role physically and psychologically.

Physical time. Participants described their physical time as president of their sport club using a diverse array of phrases, in interviews and journals, to demonstrate that the commitment was comparable to an added class and that much of their time was spent being involved with their club. Chet, in his interview, stated, "being president is [his] world." Similarly, Charlie, in his interview, said "it's really my family there so I really put all my time and effort into it, trying to make it better." Presidents physically dedicated their time to the position. The participants emphasized their participation in all club related events including community service, fundraising, and spending physical time with teammates to support their efforts with school-related work. In his interview, Chet said, "even when [teammates] need insight with school work or anything, we are always there as executive offers." In their journals, participants mentioned the physical time commitment. Gabby stated that through this experience she learned, "in order to be a 
successful leader, it takes a lot of time and dedication and also the willingness to accept the concerns and issues of other members." Additionally, William mentioned that, "it's not that I didn't expect being president to be tough, there is just always so much to do."

The documents provided a connection to the physical time required by a sport club president. The documents stated that presidents must "attend all UREC sponsored sport club meetings, approximately one per month, and training sessions." Also, the clubs are "self-administered by elected officers." These descriptions provide strong evidence that presidents of the clubs are physically involved. The documents also support that presidents spend time with faculty members such as the Assistant Director, Coordinator, and Graduate Assistant for Sport Clubs and Youth programs.

Psychological time. The presidents described their psychological time committed to their sport club in their journals using adjectives that signified stress, importance, and challenge. Gary stated, "being president was a bit overwhelming at first but as the semester has gone on I've gotten more and more comfortable in my role." Madeline said she is busy in her role as president because "making the club the best it can be is very important to me." In their interviews, participants described their commitment and dedication. In his interview, Zack stated that he “can't remember any day that I haven't thought about my club or done and try to see what I can do to improve my club." Similarly, in her interview, Gabby mentioned that she, throughout the semester, was "constantly thinking about [my club] and the role as president." As a comparison to her commitment to her role as a student, Madeline stated that she focuses on her club more than classes. She said this is because she thinks, "it's a lot of fun and I do think my role is 
very important. And I do think my classes are very important too but I just enjoy working on club stuff more."

The documents did not support the theme of psychological time. This may be because psychological time is not as clearly defined as physical time. Also, the professional staff may have been unaware of the degree of psychological time the presidents committed to their position.

\section{Discussion}

The presidents described their involvement as a valuable learning experience and therefore the campus recreation center should be viewed as a site on the learning environment map that is referenced in Keeling (2006). Student involvement is at the core of student learning and persistence. In support of this claim, Kuh, Kinzie, Schuh, and Whitt (2005) emphasize that what students to in college, or their involvement, is more related to their learning and persistence than where they attend or their personal characteristics. The themes constructed from this data support the findings of Pascarella and Terenzini (2005), who posited that students who are involved increase their leadership skills while in college. More specifically, the themes derived from this study are also found in the research of Foubert and Grainger (2006), Kuh (1993, 1995), Astin (1984), Chickering (1969) and Hall, Forrester, and Borsz (2008).

According to Kuh (1993), experiences beyond the classroom contribute to student learning and personal development. The presidents viewed their involvement as a "real world" learning experience. This out-of-class experience allowed the study participants to gain practical, social and vocational competence that will contribute to their success and performance in post-college employment. Students were involved in their role physically 
and psychologically, which contributed to these gains in competence. The intrapersonal and interpersonal challenges faced by these students increased their involvement and therefore the outcomes associated with the experience. Students who are involved in organizations during their college experience are also those who demonstrate higher levels of development in many areas (Foubert \& Grainger, 2006). According to Cooper, Healy, and Simpson (1994), leadership roles provide the opportunity to sustain and further developmental skills. The results of this study suggest that those presidents who were highly involved will use the skills developed in their lives after graduation.

\section{Social Competence}

Presidents developed their leadership abilities, public speaking, holding others accountable, and working with others, which, in turn, led to advances in confidence. Students described the difficulty of leading peers during times of conflict. This led participants to find themselves in uncomfortable situations. Through this challenge, participants learned the value of being confident in their decisions. The presidents described themselves as the ultimate person in the authority position on the team; this required them to be confident in their decision-making processes and not rely on others to reassure them. The public speaking and interpersonal skills that are required of the position allowed participants to become more confident in themselves. The involvement as a sport club president can develop a student's self-confidence, which allows them to be more confident in the classroom and more engaged with their learning.

According to Chickering (1969), students move, in multiple directions and magnitude, through seven vectors in which they psychosocially develop throughout their college experience. One of these vectors is developing competence and specifically, 
interpersonal competence. The presidents moved through this stage and gained confidence in their abilities to work with others. Not only did the development of confidence guide them through their role as president, but it also influenced participation in the classroom and assertiveness in their personal lives. For example, Elizabeth gained an ability to demonstrate assertiveness with her peers and Gary learned to share his opinions in class, which may have improved his overall understanding of the material. Involvement on campus is related to psychosocial development, or "the way [students] see themselves in relationship to others" (as cited in Evans et al., 2009, p. 76). Also, students who are more involved in co-curricular activities "score higher on scales measuring confidence and developing mature interpersonal relationships" (Evans, et. al., p. 76) In addition, Hall-Yanessa and Forrester (2004), in their study on sport club officers, found that sport club officers gain self-confidence in their abilities. Results from this study also support gains in self-confidence.

According to Yin and Ying (2010), in life beyond the college years, it is essential for students to develop interpersonal skills. Employers will desire these relational skills as "more manufacturing and labor-intensive jobs become outsourced or automated and many more careers become service oriented" (Yin \& Ying, p. 112). Students, through their involvement in leadership roles, can gain confidence in themselves and their abilities. These gains may increase their marketability for their post college employment.

Peers were mentioned frequently as instrumental to the development of leadership skills. The position not only connected them with their peers by requiring them to work alongside others, those on their executive board, and lead their teammates, but also required them to work with professional staff across campus and individuals outside of 
campus due to the requirements imposed by their leagues. The position required them to work with others, even friends, and in result, the students learned how to lead in difficult situations and hold their peers accountable.

According to Kuh (1995), Astin (1999), Chickering (1969) and Kuh, Hu and Vesper (2000), peers have powerful influence over how students spend their time. Relationships and conversations with peers have been related to gains in social competence, autonomy, confidence, self-awareness and human diversity (Kuh). According to Chickering's Theory of Student Development, the institution can have an effect on the development of a student's identity. One way that an institution can foster development in identity is through avenues in which students work together and form mature interpersonal relationships. Astin (1999) supports this too, stating, "the single most powerful source of influence on the undergraduate student's academic and personal development is the peer group and has strong effects on leadership development."

Chickering and Reisser (1993) stated that educational environments influence student development in strong ways. One of the key influences is through "friendships and student communities." Chickering and Reisser believe that meaningful friendships and diverse student communities where "shared interests exists and significant interactions occur encourage development along all seven vectors" (as cited in Evan, et.al., 2009, p. 71). The results from this study support that the sport club can be seen as a "student community" and perhaps the interactions that the presidents have with their sport club members promote their development along Chickering's seven vectors of psychosocial development. 
Haines and Fortman (2008), in their study on the impact of recreational sports on student learning, also reported gains in overall leadership development. The students in the present study suggest that involvement as president in the sport club program developed their leadership skills. Students described their experience demonstrating an altruistic leadership style where they emphasized an awareness of their teammates' needs and ability to put the interest of others before their own. In this role, presidents are developing vocational skills of teamwork and civic responsibility. The presidents learned the value of contributing to their communities in a positive way. If students can gain this experience as a sport club president, they may be in a better position to influence their constituents and positively contribute to their work environment, making it more likely for alumni at this institution to establish good rapport.

\section{Vocational Competence}

Advances in vocational competence are primarily associated with the versatility of this experience to life outside of college. Students described confidently how leading as a sport club president will transfer into their future profession such as teaching, physical therapy, finance, and coaching. This suggests that there are many transferable skill sets learned from this role. Some students described their involvement as more meaningful than their academic course work. Many students search for an internships or relevant work experience, similar to this role as the president, in order to enhance their resumes, experience, and get a competitive advantage over their peers. These students were able to take their experience and match it to that of professionals who have had "real world" job experience.

The students suggested that involvement as the president of their sport club 
allowed them to gain experience that would be comparable to that of an internship. Wankat and Oreovicz (2002) agree that since opportunities for students to practice leadership in the classroom are limited, the involvement in student organizations provides the necessary avenue in which students can develop their skills. Theory and hypothetical situations are presented in the classroom such as case studies, but students will only gain the actual experience through their participation. Perhaps this involvement on campus can provide students with the experience needed to obtain an interview or job position.

\section{Practical Competence}

Through their experience, presidents gained knowledge with the following management skills: time management, delegation, coordination and planning, and decision-making. Their involvement caused them to be physically present at many club events. In result of their participation, presidents gained experience prioritizing and had to make decisions based on their role as president, role as a student, and their social lives. Through experience delegating, the presidents learned that the role of a leader is not to take on every task, but rather trust in their constituents and create an environment of collaboration and shared responsibilities. Perhaps these presidents will be fostering positive work environments in their future.

Similarly, in their study on campus recreation leaders, Hall, Forrester and Borsz (2008) found that organizing, planning and delegating was one of the seven broad themes that emerged through participation. They found that through participation as a leader in campus recreation, management skills were improved. Additionally, Haines and Fortman (2008), in their study on the impact of recreational sports on students, found time management as a student-learning outcome. 


\section{Involvement}

According to Astin's Theory of Involvement, a student's involvement enhances their development of cognitive and affective outcomes. Additionally, the effectiveness of any educational policy or practice, in this study, that of the sport club program, is related to the extent to which it encourages students to take initiative and become actively engaged in the activity (Astin, 1984). The results of this study suggest that involvement as a president promotes involvement to the campus, which can foster cognitive and affective learning. In this particular study, the cognitive, or mental skills and affective, or feelings and attitudes, that resulted were leadership and management skills as well as confidence. These results suggest that student affairs professionals should encourage students to become physically and psychologically engaged in their commitments because this could result in similar findings.

The sport club presidents are engaged physically and psychologically. According to the data from document analysis, the sport club program creates effective policies and practices to promote involvement. The analysis of documents demonstrated the relationship of faculty to peer interaction through contact with professional staff and the graduate assistant. Astin (1999) and Chickering (1969) believe this is an effective policy or practice because of the interaction between the faculty and the student. Chickering asserted, "extensive and varied interaction among faculty and students facilitates development" (as cited in Evans, et al., 2009, p. 70).

Additionally, students described this experience as an added class, similar to an internship experience. If students are involved in the way that these sport club presidents are, they can derive similar outcomes. Professionals on the campus should encourage 
students to find leadership opportunities. In addition, professionals can create similar policies and procedures to encourage the student's involvement. Sport club professionals review the organizational structure of their program to identify any possible ways of increasing the level of involvement of other executive positions and members within the program to gain similar outcomes from their involvement.

\section{Recommendations for Practice}

This study has practical implications for sport club professionals and potential student leaders. According to Keeling (2006), “every program should have clear and specific learning outcomes and a clear link to the mission of the campus" (p. 13). There are two approaches to creating learning outcomes. The approaches are practice to outcome or outcome to practice. Outcome to practice is intentional and planned learning because the student learning outcome is identified and in result, new programs or existing programs are aligned with that outcome. The results constructed through this research provide an avenue for sport club professionals at this institution to implement outcome to practice because the themes constructed from the data can serve as student learning opportunities from involvement as a sport club president. With this stance, professionals can be intentional with programming and policy efforts. Sport club administrators, with this understanding of how sport club presidents describe their experience, should align these outcomes with program efforts to foster this development further.

Formal training is one way to create learning opportunities based on the learning outcomes. Management, leadership skills, and confidence can be highlighted in training and workshops presented to presidents in order to facilitate and support their development in these areas. Workshops that would be useful to this program include the 
following: delegation, organization, planning, time management, confidence, and leadership. Through a heightened awareness of how presidents describe their experience, professionals can prepare themselves to discuss these outcomes with the student leaders to provide an optimal level of challenge and support.

The present study's results can also guide professionals in their recruitment of future presidents. For example, social, vocational, and practical competencies were three ways students described their experience and they were found in the documents. For recruitment of this position to potential student leaders, the documents such as the job description, flyers, and information sessions should describe the position accurately and emphasize the outcomes from this study as benefits to being a sport club president. In order for potential new student leaders to fully understand the role of president, the position could be described by using the themes constructed from this study as benefits to being a sport club president. Recruitment documents could include that candidates can become more self-confident and confident working with others from this role and that they will be able to gain transferable skills that can contribute to the post college employment. Emphasis should be placed that this role can serve as an internship experience and that learning and development does occur outside of academics.

Additionally, if students are unsure of whether they want to run for president, the theme of self-confidence should be promoted. Since self-confidence is gained through this role, students do not have to feel confident in their abilities and working with others before applying for this position. Confidence was not included in the documents. This may not be a focus of the program and may be difficult to portray in written documents. However, professionals, in their conversations with potential new student leaders, should 
emphasize the gain in self-confidence that could result from their involvement. Finally, the amount of psychological involvement should be emphasized; the dedication and commitment the students will need to demonstrate in order to derive similar outcomes should be emphasized and highlighted during the recruitment process. This, and the four themes constructed from this data should also be included in the description of the president in the Sport Club Manual. This transparency will guide students to cope with the position at the onset.

Due to this institution's emphasis on student leadership, other sport club programs may change their current model and mimic this institution's in order for the likelihood of similar outcomes. Practitioners can be aware of the impact that a role that requires a high level of involvement can have on a student's college experience. Programs should promote student-led initiatives and philosophies in order to derive similar outcomes. The student's amount of physical involvement should be promoted and encouraged through policies and procedures. Physical involvement can be manipulated through the use of policies and procedures such as the amount of meetings and workshops a president is required to attend to the amount of forms that need to be completed.

Through the emphasis on involvement constructed from the data, students and professionals should be made aware that those students who are more physically and psychologically invested gain more educationally purposeful outcomes from their experience. According to Astin (1984), this particular program should be classified as effective because of the amount of student initiative and engagement. Institutions that have the resources and ability to modify their programs to align similarly with the structure, policies, and practices as this should consider doing so to gain similar 
outcomes. Specifically, sport club professionals should review the organizational structure of the program to identify any possible ways of increasing the level of involvement of other executive positions and members within the program to gain similar outcomes from their involvement.

\section{Chapter Summary}

After an analysis of data from the journals, interviews, and documents, four themes emerged: social competence, vocational competence, practical competence, and involvement. These themes describe a sport club president's experience and how this participation affects their college experience, and gives insight into how presidents perceive their development. The presidents were physically and psychologically involved and gained skills, behaviors, and attitudes related to vocational, social and practical competence. These findings support that the campus recreation center is a site on the learning environment map of the college campus. 


\section{Chapter 5: Conclusions and Future Research}

This research provides insight into how involvement in a leadership position within a sport club programs shaped college students' experiences. The themes constructed demonstrate the participant's development of skills in management, leadership, and confidence while being both physically and psychologically involved. The purpose of this research was to give insight into how sport club presidents describe their involvement, how their involvement shapes their college experience and how presidents perceive their development as a result of their involvement. Sport club presidents describe themselves as being both physically and psychologically involved in their experience. This experience shapes their college experience because of the physical and psychological time they committed. This commitment shaped their everyday schedules and some found this experience just as meaningful, if not more significant, than their academic work. Finally, the presidents perceived their development by progressing their social, vocational, and practical competencies.

Campus recreation, through leadership opportunities, supports learning outcomes in college and addresses vital questions related to the purpose of a student's involvement on the campus. Questions answered included: What did students learn? What differences did [sport club leadership opportunities] make on their lives?" (Keeling, 2006). Students learned skills that enhanced their development and marketability for future employment. Campus recreation, through a sport club program, provides students with an opportunity to become both physically and psychologically involved and increase their developmental capabilities.

The sport club program and other campus recreation programs offer meaningful 
opportunities for students to learn through their participation in co-curricular

programming and thus should be viewed as an avenue that makes a difference in the lives of students. According to Yin and Ying (2010), fostering leadership skills in students "provides another value-added characteristic that will help students compete with their international peers" (p. 61). Consequently, the college environment must prepare students for a life that is rapidly changing into a global economy. As the analysis of this study revealed, the sport club program at this institution can improve a student's personal development through the gain of vocational skills. This form of involvement served as an avenue for participants to gain valuable experience, which allowed them to articulate how they will be able to contribute to their future places of employment in positive ways.

When the presidents learned to work with teammates and friends, they also learned to negotiate conflict in their personal lives. When they were required to speak during team meetings and practices, they acquired skills that were later utilized in the classroom setting. The skills gained through this involvement were transferred into their personal and professional lives. Moreover, all students, regardless of their abilities at onset, should be encouraged, challenged, and supported to pursue leadership positions in order to better position themselves to gain relevant student-learning outcomes, which will prepare them to be future leaders both in and out of the classroom.

In addition to the sport club president position, other executive positions require physical and psychological commitment. Therefore, the experiences of other leadership roles within the program should be explored. This exploration would give further insight into how other sport club leaders develop through their participation. Furthermore, interactions between the members on executive boards (e.g. president, vice-president, 
secretary, treasurer) ought be examined to investigate if student leaders foster or enhance the development of one another. This type of exploration can give insight into the significance of peer groups on a student's development. 


\section{Appendix A: Letter for Research Site Approval}

May 6, 2013

Eric Nickel

Director, University Recreation

701 Driver Drive

Harrisonburg, VA 22807

Dear Mr. Nickel:

As you may know, I am in the process of completing a Master's degree in Campus Recreation Leadership. I am working to create a proposal for a research study which will serve as my thesis in the program. I would like to use University Recreation as the research site for my study. The purpose of my study is to explore how Presidents of Sport Clubs describe their experience and how the students perceive their leadership role.

I would like to use the Presidents of the Sport Clubs for the participants within my study. I spoke with the Assistant Director of the Sport Club program, Chris Jones, to gain initial interest and explain the purpose of my study. He supports this project. Participation in this study will be voluntary for any students that are interested and there will be no incentive provided. Data will be gathered during the fall semester of 2013.

This study will employ a qualitative approach and more specifically be conducted as a case study. I will use reflective journaling, document analysis and interviews as three of my methodology approaches. Reflective journaling will require the participants to remain engaged in my study throughout the fall semester. I will use the documents provided to the Presidents, such as the Sport Club Manual and forms, to gain more information as to whether underlying themes exist, which may influence the President's leadership role. All names and the organizational name, James Madison University, will remain confidential throughout the study.

If you approve of the study and the use of the student Presidents as research subjects, I will need a formal letter from you starting that you do agree, any requirements you have in order to meet departmental and university protocol. This project will go through the JMU IRB approval process. If you have any questions, please feel free contact me (484-375-3677) or my supervisor, Julie Wallace Carr (540-568-7341).

Thank you for your consideration, 


\section{Appendix B: Recruitment Email}

Hello club sport presidents,

You are invited to take part in a research study. Before you decide to participate in this study, you need to understand the risks and benefits associated. As a student in the Campus Recreation Leadership Program here at James Madison University, I am conducting a research study that will serve as my Master's thesis. My study will explore how presidents of a particular club sport describe their involvement. The research will be conducted at the University Recreation center and will take place throughout the course of twelve weeks. As a participant, you will be asked to participate in an interview that will last approximately 30 minutes. You will also electronically submit a journal each week and submit a one paragraph response. The total amount of hours will be approximately thirteen hours over the next twelve weeks.

This study will have no more risk of harm than you would experience in your everyday life. Your participation in this research study is voluntary and you may begin to stop your participation at any time. You will not be identified by name at any point throughout the study; all records will be confidential.

If you have any questions about the procedures of this research study, please contact me, Megan Flosdorf (flosdoml@jmu.edu).

Thank you for your consideration,

Megan Flosdorf 


\section{Appendix C: Recruitment Briefing Information Sheet}

You are invited to take part in a research study. Before you decide to participate in this study, you need to understand the risks and benefits associated. As a student in the Campus Recreation Leadership Program here at James Madison University, I am conducting a research study that will serve as my Master's thesis. My study will explore how presidents of a particular club sport describe their involvement. The research will be conducted at the University Recreation center and will take place throughout the course of twelve weeks. As a participant, you will be asked to participate in an interview that will last approximately 30 minutes. You will also electronically submit a journal each week and submit a one-paragraph response. The total amount of hours will be approximately thirteen hours over the next twelve weeks.

This study will have no more risk of harm than you would experience in your everyday life. Your participation in this research study is voluntary and you may begin to stop your participation at any time. You will not be identified by name at any point throughout the study; all records will be confidential.

If you are interested in participating, please fill out this consent form. After completion, you will be emailed in a week to set up a time to meet with me at the university recreation center. At this meeting, we will go over requirements for participation, create a pseudonym and set an interview time for later in the semester.

If you have any questions about the procedures of this research study, please contact me, Megan Flosdorf (flosdoml@jmu.edu). 


\section{Appendix D: Consent Form}

\section{Consent to Participate in Research}

\section{Identification of Investigators \& Purpose of Study}

You are being asked to participate in a research study conducted by Megan Flosdorf and Julie Wallace Carr from James Madison University. The purpose of this study is to gain insight into how students describe their experience as a president of the club sport within the program. This study will contribute to the researcher's completion of her master's thesis.

\section{Research Procedures}

Should you decide to participate in this research study, you will be asked to sign this consent form once all your questions have been answered to your satisfaction. This study consists of an interview that will be administered to individual participants in the University Recreation Center. You will be asked to provide answers to a series of questions related to provide insight into how presidents describe their experience in the club sport program. The interview will be audio recorded.

The study also consists of required journal entries each week that will be administered to individual participants via email from the researchers. You will be asked to write a paragraph response to the prompt given. The journal entries will be collected weekly and turned in to Megan Flosdorf's mailbox in the University Recreation Center.

\section{Time Required}

Participation in this study will require 30 minutes of your time for the interview. You will also be required to submit a one paragraph journal entry each week.

\section{Risks}

The investigator does not perceive more than minimal risks from your involvement in this study (that is, no risks beyond the risks associated with everyday life).

The investigator perceives the following are possible risks arising from your involvement with this study: the completion of journal entries could elicit emotional feelings related to stress. The researcher will suggest services provided on campus for all participants who begin feeling this way.

\section{Benefits}

There are no direct benefits to the participation in this study. The research will benefit the club sport program at James Madison University. The research will enlighten administrators of the program on the presidents perspective on their experiences.

\section{Confidentiality}

The results of this research will be presented as Megan Flosdorf's Graduate Thesis in a classroom setting. The results of this project will be coded in such a way that the respondent's identity will not be attached to the final form of this study. The researcher retains the right to use and publish non-identifiable data. While individual responses are confidential, aggregate data will be presented representing averages or generalizations about the responses as a whole. All data will be stored in a secure location accessible only to the researcher. Upon completion of the study, all information that matches up individual respondents with their answers, including audio tapes) will be destroyed. 


\section{Participation \& Withdrawal}

Your participation is entirely voluntary. You are free to choose not to participate.

Should you choose to participate, you can withdraw at any time without consequences of any kind.

\section{Questions about the Study}

If you have questions or concerns during the time of your participation in this study, or after its completion or you would like to receive a copy of the final aggregate results of this study, please contact:

Megan Flosdorf Julie Wallace Carr

University Recreation Hospitality, Sport \& Rec Management

James Madison University James Madison University

flosdoml@jmu.edu Telephone: (540) 568-7341 wallacje@jmu.edu

\section{Questions about Your Rights as a Research Subject}

Dr. David Cockley

Chair, Institutional Review Board

James Madison University

(540) 568-2834

cocklede@jmu.edu

\section{Giving of Consent}

I have read this consent form and I understand what is being requested of me as a participant in this study. I freely consent to participate. I have been given satisfactory answers to my questions. The investigator provided me with a copy of this form. I certify that I am at least 18 years of age.

I give consent to be (video/audio) taped during my interview. (initials)

Name of Participant (Printed)

Name of Participant (Signed)

Name of Researcher (Signed)
Date

Date 


\section{Appendix E: Journal Instructions}

For the 12 weeks of the study, you will be required to journal once a week. This journal will require you to reflect on your experiences as the president of your club sport. All entries should be at least one paragraph long. Please refer to yourself and label your journal entry using your pseudonym.

Please email journal entries to scpresident13@gmail.com by 10 p.m. each Sunday with your pseudonym in the subject line of the email. A copy of your journal will be kept at the desk of Megan Flosdorf in room 105 at the University Recreation center. Your submissions will remain anonymous throughout the duration of the study. 


\section{Appendix F: Interview Guide}

1. Describe your involvement so far as the president.

2. Involvement: physical and psychological amount of time devoted, How many hours, would you say you commit per week to the team as the president?

3. How do you, describe your level of commitment (time in the club, how does this shape your week)?

4. Did your day-to-day life change as a result serving as the president?

5. What is the most significant experience you have had as the president?

6. Does your involvement as president of your club benefit you? How so?

7. Does your involvement as presidents of your club challenge you? How so?

8. Do you have any learning experience(s) from your role as the president that you deem significant? If so, can you describe the experience(s)? Also, what did you learn from the significant experience(s)?

9. Can you give me an example of how have your experiences as president shaped your future career aspirations? What do you want to do with your life? How so?

10. Have your experiences as president shaped your perspective about leadership?

11. How have your experiences changed you as a person?

12. Is there anything about serving as the president of you club that may continue to shape you after you leave this university?

13. Is there anything you want to add? Any question you thought I would ask? 


\section{References}

Abrahamowicz, D. (1988). College involvement, perceptions and satisfaction: A study of membership in student organizations. Journal of College Student Development, 29(3), 233-237.

Arnold, J. (1975). Club sports in colleges and universities. Journal of Physical Education and Recreation, 46-52(4), 19-22.

Astin, A. (1984, 1999). Student involvement: A developmental theory for higher education. Journal of College Student Development, 40(5), 518-529.

Barcelona, B. (2002). Student involvement in campus recreational sports activities and gains in team-functioning. LARNet, The Cyber Journal of Applied Leisure and Recreation Research, 1-15.

Baxter, P., \& Jack, S. (2008). Qualitative case study methodology: study design and implementation for novice researchers. The Qualitative Report, 13(4), 544-559.

Becker, C. Cooper, N., Atkins, K., \& Martin, S. (2009). What helps students thrive? An investigation of student engagement and performance. Recreational Sports Journal, 33, 139-149.

Bowen, G. (2009). Document analysis as a qualitative research method. Qualitative Research Journal, 9(2), 27-40.

Carruthers, C., Busser, J., Cain, C., \& Brown, C. (2010). Students' experiences and outcomes from participation in an extracurricular club. A Journal of Leisure Studies and Recreation Education, 25, 36-53.

Chickering, A. (1969). Education and Identity. San Fransisco: Jossey-Bass. 
Chickering, A., \& Reisser, L. (1993). Education and identity (2nd ed.). San Francisco: Jossey-Bass.

Cooper, D., Healy M., \& Simpson, J. (1994). Student development through involvement: Specific changes over time. Journal of College Student Development, 35(2), 98102.

Crabtree, B., \& Miller, W. (1999). Doing qualitative research. London: SAGE Publications, Inc.

Creswell, J. (1998). Qualitative inquiry and research design. Thousand Oaks, CA: SAGE Publications, Inc.

Dalgarn, M. (2001). The role in the campus recreation center in creating a community. NIRSA Journal, 25(1), 66-72.

Dixon, M., \& Warner, S. (2013). Sports and community on campus: Constructing a sports experience that matters. Journal of College Student Development, 54(3), 283-298.

Dugan, J., \& Komives, S. (2007). Developing leadership capacity in college students: Findings from a national study. A report from the multi-institutional study of leadership. College Park, MD: National Clearinghouse for Leadership Programs.

Evans, N., Forney, D., Guido, F., Patton, L., \& Renn, K. (2009). Student development in college: theory, research and practice. Location: John Wiley \& Sons.

Foubert, J., \& Grainger, L. (2006). Effects of involvement in clubs and organizations on the psychosocial development of first-year and senior college students. NAPSA Journal, 43(1), 166-182.

Gellin, A. (2003). The Effect of Undergraduate Student Involvement on Critical 
Thinking: A Meta-Analysis of the Literature. Journal of College Student Development, 44(6), 746-762.

George, A., \& Bennett, A. (2004). Case Studies and Theory Development in the Social Sciences. Cambridge: The MIT Press.

Guido-DiBrito, F., \& Batchelor, S. (1988). Developing leadership potential through student activities and organizations. New Directions for Student Services, 44, 5162.

Hackett, M. (2007). Exploring the relationship between recreational sports employment and academic Success. Recreational Sports Journal, 31, 69-74.

Haines, D. (2001). Undergraduate student benefits from university recreation. Recreational Sports Journal, 25(1), 25-33.

Haines, D., \& Fortman, T. (2008). The college recreational sports learning environment. Recreational Sports Journal, 32, 52-61.

Hall-Yannessa, S., \& Forrester, S. (2004). Differences in leadership development of club sports officers. Recreational Sports Journal, 28(1), 7-18.

Hall-Yanessa, S., \& Forrester, S. (2005). Impact of advisor interaction on the development of leadership skills in club sports' officers. Recreational Sports Journal, 29(1), 9-21.

Hall-Yanessa, S., Forrester, S., \& Borsz, M. (2008). A constructivist study examining the leadership development of undergraduate students in campus recreational sports. Journal of College Student Development, 49(2), 125-140.

Harvey, L. (2011). Intimate reflections: private diaries in qualitative research. Qualitative Research, 11(6), 664-682. 
Henchy, A. (2011). The influence of campus recreation beyond the gym. Recreational Sports Journal, 35, 174-181.

James Madison University Recreation. University Recreation, n.d. Web. 31 Mar. 2014. <http://www.jmu.edu/recreation/sport-clubs/resources/index.shtml >.

James Madison University Sport Club Manual. (2012-2013). James Madison University, Virginia.

Jick, T. (1979). Mixing qualitative and quantitative methods: Triangulation in action. Administrative Science Quarterly, 24, 602-611.

Keeling, R. (Ed.) (2006). Learning reconsidered 2: Implementing a campus-wide focus on the student experience. Champaign: Human Kinetics.

Koelsch, L. (2013). Reconceptualizing the member check interview. International Journal of Qualitative Methods, 12(1), 168-179.

Kuh, G. (1993). In their own words: What students learn outside the classroom. American Educational Research Journal, 30(2), 277-304.

Kuh, G. (1995). The other curriculum: Out-of-class experiences associated with student learning and personal development. Journal of Higher Education, 66(2), 123-155.

Kuh, G. (2001). Assessing what really matters to student learning: Inside the National Survey of Student Engagement." Change, 33(3), 10-17.

Kuh, G., Hu, S., \& Vesper, N. (2000). They shall be known by what they do: An activities-based typology of college students. Journal of College Student Development, 41(2), 228-244.

Kuh, G., Kinzie. J., Schuh, J., \& Whitt, E. (2005). Student success in college: Creating conditions that matter. San Francisco, CA: Jossey-Bass. 
Krefting, L. (1991). Rigor in qualitative research: The assessment of the trustworthiness. The American Journal of Occupational Therapy, 45(3), 214-222.

Kvale, S., \& Brinkmann, S. (2009). Interviews: Learning the craft of qualitative research interviewing. Thousand Oaks, CA: SAGE Publications, Inc.

Lifschutz, L. (2012). Club sports: Maximizing positive outcomes and minimizing risks. Recreational Sports Journal, 36(2), 104-12.

Merriam, S. (2009). Qualitative research: A guide to design and implementation. San Francisco, CA: Jossey-Bass, Inc.

Moore, J., Lovell, D., McGann, T., \& Wyrick, J. (1998). Why involvement matters: A review of research on student involvement in the collegiate setting. College Student Affairs Journal, 17(2), 4-17.

National Intramural Sports Association (2008). Campus recreation: Essentials for the professional. Champaign: Human Kinetics.

Paré, G. (2001). Using a positivist case study methodology to build and test theories in information systems: illustrations from four exemplary studies. Montreal: Montreal.

Pascarella, E. (1985). College environmental influences on learning and cognitive development: A critical review and synthesis. In J. Smart (Ed.), Higher education: Handbook of theory and research, 1, 1-64.

Pascarella, E., \& Terenzini, P. (2005). How college affects students: A third decade of research. San Francisco: Jossey-Bass.

Pennington, B. (2008). Rise of college club teams creates a whole new level of success. The New York Times: Print. 
Searle, J. (1995). The Construction of social reality. New York, NY: Free Press. Empowering and constraining beliefs. NASPA Journal, 42(1), 111-131.

Stake, R. (1995). The art of case study research. Thousand Oaks, CA: SAGE Publications, Inc.

Taylor, S., \& Bogdan, R. (1984). Introduction to Qualitative Research Methods: The Search for Meanings. New York: Wiley.

Todaro, E. (1993). The impact of recreational sports on student development: A theoretical model. Recreational Sports Journal, 17(3), 23-26.

Toperzer, L., Anderson, D., \& Barcelona., R. (2011). Best practices in student development for campus recreation professionals. Recreational Sports Journal, 35, 145-156.

Tsiotsou, R. (1998). A survey of sport club programs. Recreational Sports Journal, 22(2), 38-41.

Tsigilis, N., Masmanidis, T., \& Koustelios, A. (2009). University students'satisfaction and effectiveness of campus recreation programs. Recreational Sports Journal, 33, 65-77.

Wankat, P., \& Oreovicz, F. (2002). The world is a classroom. ASEE Prism, 11(5), 36.

Weese, J. (1997). The Development of an instrument to measure effectiveness in campus recreation programs. Recreational Sports Journal, 11, 263-274.

Weis D. (2007). The “ultimate” experience: Participation in club sports a source of women's development in college (Master's thesis). Retrieved from Western Washington University, Washington. 
Yin, R. (2009). Case study research: Design and methods. Thousand Oaks, CA: SAGE Publications, Inc.

Yin, A., \& Ying, L. (2010). Assessing personal growth. New Directions for Institutional Research, 1, 111-123. 